\title{
Social Welfare Analysis of Investment Public-Private Partnership Approaches for Transportation Projects
}

\author{
(Forthcoming in Transportation Research A)
}

\author{
Omid M. Rouhani ${ }^{1}$, R. Richard Geddes², H. Oliver Gao ${ }^{3 *}$, and Germà Bel ${ }^{4}$ \\ ${ }^{1}$ School of Civil and Environmental Engineering, Cornell University, Hollister Hall, Ithaca, NY 14853, USA; Email: \\ om67@cornell.edu Tel: +1 5302048576 \\ 2 Department of Policy Analysis and Management, Cornell University, 251 Martha Van Rensselaer Hall, Ithaca, NY 14853, \\ USA; Email: rrg24@cornell.edu \\ $3^{3 *}$ Corresponding author, School of Civil and Environmental Engineering, Cornell University, Hollister Hall, Ithaca, NY 14853, \\ USA; Email: hg55@cornell.edu \\ ${ }^{4}$ Departament de Politica Econòmica, Universitat de Barcelona, Avd. Diagonal 690, 08034 Barcelona, Spain; Email: \\ gbel@ub.edu
}

\begin{abstract}
This paper has two objectives: (i) to introduce a new approach in order to gain widespread support for road pricing; and (ii) to develop a detailed social welfare analysis for road pricing schemes. We first describe our novel approach that stimulates public support for road pricing, which we refer to as an investment public-private partnership, or IP3. This approach returns a significant portion of the economic value created by road pricing back to the citizens who own the newly priced facility. We then present a social welfare framework that estimates the benefits and costs of using the IP3 approach on an urban transportation network. A P3 project's impact on overall social welfare provides a more comprehensive evaluation criterion than the often-used Value for Money (VfM) analysis. Apart from several theoretical studies, a detailed social welfare analysis that includes all major P3 project stakeholders is absent from the literature. We use Fresno, California as our case study in order to conduct a welfare analysis on IP3s. Our results show that system-optimal tolling favors average users, but that government - and consequently taxpayers-should pay for costly tolling systems (negative profits). In contrast, unlimited profit-maximizing tolls raise substantial profits for government, for the infrastructure's citizen-owners, and for the private sector, but the average user is worse off. From a social-welfare perspective, one should search for a Pareto improvement under which all major stakeholders are better off. Our estimates indicate that a mixed public and private tolling scheme offers such an improvement.
\end{abstract}

Keywords: social welfare analysis; investment public private partnerships; residents; road concession; urban transportation systems; road pricing. 


\section{Introduction}

The question of which type of transportation facilities, business models, and ownership structures underpin successful public-private partnerships (P3s) is becoming more relevant for both public- and private-sector infrastructure stakeholders. Answers may lie in exploration of new and innovative policy approaches that capture the potential of $\mathrm{P} 3 \mathrm{~s}$ to address endemic infrastructure funding, project delivery, and service quality challenges (Rouhani, 2012).

In response to such growing concerns, Geddes and Nentchev $(2013,2014)$ suggest a new approach, called an investment public-private partnership, or IP3,. The IP3 offers a strategy that could increase public support for system-wide pricing of existing roads. The approach does so by releasing economic value embedded in transportation facilities that cannot be realized since road use is not priced. The approach explicitly recognizes the right of the citizens who own public infrastructure to receive income generated from it. Such rights are rarely, if ever, recognized. By encouraging road pricing, the IP3 approach also facilitates additional investment in transportation infrastructure. We describe the IP3 approach in detail in Section 2 below.

The first step to evaluate an IP3 (and in general, any project) is to determine the appropriate criterion in order to measure the project's potential benefits and costs. The relevant criterion determines whether or not the approach serves the overall public interest. Government agencies often evaluate P3 projects using Value for Money (VfM) analysis (Yuan et al., 2009), but the most appropriate evaluation criterion is overall social welfare (Boardman and Vining, 2012). In fact, VfM analysis might lead to the implementation of projects that reduce social value since it accounts only for the costs of project development; the benefits to users or consumers are excluded (Heald, 2003; Boardman and Vining, 2010).

VfM studies also often use inappropriately high discount rates (Johnston, 2010). To provide a detailed social welfare analysis, major stakeholders' gains and losses from using a P3 should be compared to the gains and losses from a traditional (i.e., public-procurement only) approach to providing the same infrastructure or service.

Theoretical modeling of social welfare associated with private operation of priced roadways has examined the effects of duopoly and monopoly structures (Zhang, 2008; Winston and Yan, 2011; Rouhani et al., 2013a), the effects of traffic diversion to secondary roads (Swan and Belzer, 2010), and the impact of alternative privatization structures and regulations (Yang and Meng, 2000; Tan et al. 2010; Zhang and Yusufzyanova, 2012). Such studies have focused mainly on system travel time on a few selected roads only. None have developed a detailed analysis including various welfare components in P3 implementation.

In the congestion pricing context, Parry and Bento (2002) analyzed social welfare interactions between direct peak-period congestion pricing and "second best" factors, including congestion on unpriced routes, as well as accident and pollution externalities. Safirova et al. (2004) examined the welfare effects of various road pricing schemes for the Washington, DC, metropolitan area. Major factors in those analyses were changes in travel time and tolls paid. Social welfare studies generally impose strong assumptions regarding implementation of the same toll rates on all roads, application of a macro model (with limited details about system components), and exclusion of externalities other than travel-timebased congestion. In contrast, we show that the key impacts of the IP3 approach can be captured within the boundaries of urban cities. Our approach estimates important and complex interrelations between different components of an urban transportation system and between different stakeholders within the IP3 approach. 
A detailed social welfare analysis that includes all major $\mathrm{P} 3$ project stakeholders (residents, users, government, and the private sector) is absent from the literature. To fill this gap, we focus on developing a general framework for social welfare analysis that includes major stakeholders within an IP3 approach. We next describe the modeling required for evaluating an IP3 scheme in an urban transportation context, and estimate the social welfare change from implementing IP3 alternatives for a major urban city: Fresno, California. Although our focus is on the IP3 approach, our modeling framework can be generalized to other P3 models, such as Greenfield projects, and to similar tolling (i.e., road pricing) schemes.

\section{The Investment Public-Private Partnership}

There is widespread agreement among transportation economists that many problems associated with the delivery, operation, and maintenance of transportation infrastructure could be addressed through the adoption of system-wide road pricing (Vickrey, 1992), e.g., charging motorists a variable per mile fee for road use (Velaga and Pangbourne, 2014). Such fees are often referred to as mileage-based user fees or MBUFs (Burris et al., 2013). Researchers have however recognized that this represents a major policy change, and that motorists are likely to resist road pricing.

There is a growing multi-disciplinary literature on strategies for enhancing public acceptance of road pricing. Small $(1983,1992)$ and Anderson and Mohring (1996) stress that added revenue from road pricing must be used prudently in order to gain public acceptance. Small (1992) suggests using a portion of new revenues for tax reductions and rebates in the relevant region and the remainder for regional transportation improvements. King et al. (2007) argue for allocating revenues to the jurisdictions (e.g., cities and towns) through which newly priced freeways extend. Kockelman and Kalmanje (2005) analyze what they call credit-based congestion pricing. They suggest rebating toll credits (equal to average monthly usage) back to motorists. Arnold et al. (2012) suggest enhancing public acceptance by increasing motorists' travel choices. They recommend converting the shoulder of a highway into a new general purpose lane while converting the left lane into a high-occupancy toll (HOT) lane. Other suggested approaches include toll revenue "recycling" in which toll revenues are rebated back to motorists (Parry and Bento, 2001).

Although innovative, the above proposals generally ignore the role of the citizens who actually own the infrastructure. A basic tenet of property law is that asset owners possess the right of fructus, which is the right to retain the fruit, produce, or to profit from an asset (Garner and Black, 2009). U.S. transportation infrastructure assets are almost completely citizen-owned, which implies that the relevant jurisdiction's citizens have a claim to asset-generated income. ${ }^{1}$ The IP3 approach is novel in that it recognizes such rights explicitly. We thus refer to asset owners as citizen-owners.

In an IP3, wealth latent in transportation infrastructure is realized by leasing (i.e., concessioning) and pricing existing (un-priced) transportation facilities. The highest value is attained by competitive bidding among potential concessionaires for the right to operate the facility and collect tolls. The

\footnotetext{
${ }^{1}$ One could make the argument that previous taxpayers (mostly those paying fossil fuel taxes) should realize some of the value generated by the road via the concession. This raises two considerations. First, the transaction cost of locating previous fuel-tax payers from the past is prohibitively high. Relying on current residency to determine eligibility for dividends has a much lower cost. Perhaps more importantly, this conflates customers with asset owners. The customers of a steel mill, for example, should not receive part of the value realized from an Initial Public Offering (IPO) of the steel mill. Their value was received in the form of consumer surplus from the steel purchased. Just as the value from the IPO should go to the mill's owners, the value realized from the concession payment, which reflects the discounted present value of future profits from the road, should go to its citizen-owners.
} 
payment would reflect the discounted present value of the expected net cash flows from newly priced facility. That value is then preserved using a public permanent fund. Permanent funds exist in a variety of jurisdictions to preserve capital in perpetuity and to insulate natural-resource-generated wealth from political spending pressure. ${ }^{2}$ Some portion of investment income is typically paid out to the facility's citizen-owners (Geddes and Nentchev, 2013).

Note that there is now a substantial experience implementing tolling schemes in already existing roads, especially in urban areas (Albalate et al., 2009). In addition, the idea of IP3 could be applied to the provision of new, in addition to existing, infrastructure. However, because an increase in transportation supply generally induces more demand and may further deteriorate urban transportation systems in long run, we do not suggest the IP3 approach for new infrastructure.

We next describe steps in adopting an IP3 in detail. The first step for the relevant transportation authority is to decide if the IP3 approach is appropriate for their road system. This requires careful consideration not only of the efficacy of system-wide road pricing, but also of the creation of a permanent fund to preserve value for citizen-owners and to generate dividends. Public IP3 sponsors may also wish to carefully consider the distribution of upfront concession lease proceeds between additional investment in the permanent fund versus current expenditures, as well as the regulation of P3s through the concession contract. ${ }^{3}$

The second step is to determine the preferred contractual structure for the concession (Buxbaum and Ortiz, 2009). P3 contracts are critical because they govern the relationship between the public project sponsor and the private partner for the concession's duration. The public project sponsor should carefully consider alternative contractual arrangements before soliciting bids. Key considerations include the level(s) of tolls and their flexibility. Other contractual issues include desired service levels (such as quality of signage, line paint, snow removal, and responsiveness to disabled vehicles, among others), how those service levels are measured, standards for maintenance and expansion, and how performance is incentivized using explicit penalties and rewards. Linking toll increases to the consumer price index, for example, creates a stable, inflation-protected revenue stream that is likely to attract a larger upfront concession payment, and thus offer greater dividend payments to residents out of the permanent fund. In addition, caps on tolls are helpful in controlling the problems of market power and of congestion on nearby un-priced roads (Rouhani et al., 2013).

The third step is for the public sponsor to announce a request for qualifications (RFQ) to attract and screen qualified bidders for IP3 concession leases. Bidders often include a road operator and a financier cooperating through a legal entity created specifically for the purpose of bidding on, financing, maintaining, and operating the facility or network in question. This involves all the standard procedures for assessing potential bidders in a major transportation project.

Conditional on the preset concession terms, the bidder offering the largest upfront concession payment is awarded the contract. Concession bidding effectively converts producer-side value (i.e., the discounted profit stream from the road) enabled by road pricing into an upfront payment for citizen-

\footnotetext{
${ }^{2}$ The largest U.S. example of a public permanent fund is the Alaska Permanent Fund, which was established in 1976 to preserve natural resource wealth for its citizen-owners, and is now valued at about $\$ 51$ billion. See http://www.apfc.org/home/Content/home/index.cfm (accessed August 10, 2014). Other examples include the Alberta Heritage Savings Trust Fund and the Texas Permanent School Fund. Public permanent funds are particular types of sovereign wealth funds.

${ }^{3}$ Additional current expenditures may include the improvement and creation of alternative transportation modes within the newly priced system. Those alternatives might include new bike paths, bus rapid transit, and improved fixed guideway options, among others.
} 
owners. Bidding also ensures that infrastructure owners receive the most value for the income stream generated by their assets. This generates the largest annual dividend possible for citizen-owners. Once the winner is selected, and the lease agreement is concluded, some fraction of the concession payment is used to capitalize the citizens' permanent fund. The remainder can be used to improve transportation in the same area or corridor as the newly priced network. This provides motorists using priced facilities with either an expanded road network, with additional transportation options, or both.

The fourth step is to use some of the concession fee proceeds to capitalize the public permanent fund. The public sponsor must determine the permanent fund's legal structure and how to best insulate its capital from short-term political spending pressure. The Alaska Permanent Fund (APF), for example, is protected explicitly in the state's constitution (Olson and O'Brien, 1990). The public sponsor can glean lessons from other successful permanent fund models including those used in Alaska, Alberta, Texas, and Norway. The permanent fund preserves wealth in perpetuity since the fund's principal is never spent. Concession fee proceeds could be invested in a broad, diversified portfolio of financial instruments. Transparent commitments of capital help protect the fund from political spending pressure, in addition to any legal protections it may enjoy.

The fifth step is to price the road network using variable tolls, and to begin operations under the private concessionaire. The terms of the concession contract govern the system operation is then governed by the terms of the concession contract, which addresses key issues such as control of market power, asset maintenance, and service quality.

The final step is to ascertain the appropriate size of dividend payments to citizen-owners and initiate annual distribution. Dividends are paid out of investment income generated by the fund's investments. ${ }^{4}$ The public sponsor is responsible for establishing the method through which those dividends are calculated and who is eligible. Because the fund exists in perpetuity, fund-generated income grows if new lanes and facilities are added to the priced network and as existing facilities are reconcessioned. Unlike a natural resource were extraction creates a once-and-for-all payment, such as oil, a road network is used repeatedly, generating ongoing consumer surplus for drivers and producer surplus for road owners. If, for example, a road concession lasts 15 years, then the network's citizenowners can receive another concession payment in 15 years. Many other decisions impact the size of annual dividends to citizen-owners. Some permanent funds, including Alaska's, choose to reinvest a portion of their investment income back into the fund to foster growth in principal.

Some scholars suggest road concession payments (or profits from road pricing) could be used to lower taxes in the jurisdiction, such as sales taxes (see e.g., Small, 1992). The IP3 approach can be modified to provide such tax reductions and is not limited to direct payments. However, economic studies suggest that direct payments are superior tools to lowering taxes because reductions in sales taxes are not as salient to taxpayers as receiving direct dividend payments. They are thus less likely to generate support for pricing (see e.g., Finkelstein, 2009).

The IP3 allows private infrastructure investment to furnish households with an annual payment to offset their cost of paying road prices. This increases public support for adopting system-wide road pricing. Experts have recognized that the creation of a broad beneficiary group is critical for the introduction of tolls and the acceptance of private participation (King et al., 2008; Gomez-Ibanez, 2006).

4 Although giving citizens dividends or giving them a proportion of toll revenue directly may seem similar, the arrangement of including a permanent fund to invest the concession payment and generate dividends is in fact a critical institutional difference. This arrangement preserves value (and generates dividends) forever, whereas toll revenue, even if originally earmarked to go to infrastructure, may be diverted over time. 
This is consistent with distributing investment proceeds to all eligible households in the jurisdiction via annual payments.

Importantly, the IP3 approach is not merely a redistribution of wealth from road users to the jurisdiction's citizens. It creates net social value in the form of new consumer and producer surplus through the system-wide adoption of variable road pricing (see e.g., Perloff, 2011) and by competition for the concession. A simple, but underappreciated, insight from our analysis is that neither type of social value can be realized unless the service in question is priced appropriately. Unless taxpayers provide guaranteed revenue from some other source, private partners will refuse to invest if the road system is un-priced. The IP3 thus offers a new way of realizing system-wide unit pricing so as to realize added economic value. Granting citizens annual dividends in return helps achieve that goal.

The IP3 approach and other elements of our analysis can be adjusted to account for alternative political constraints, limitations, and conditions in practice. An example might be differing legal structures across jurisdictions. There are several variables that public-sector sponsors can adjust to ensure acceptance, including the proportion of the concession payment used to capitalize the fund, the concession length, and the size of the annual dividend, among others. If, for some reason, it is undesirable to incorporate private road operation under a franchise/concession agreement, then municipalities can simply sell bonds against the new stream of toll revenues in order to raise the upfront payments to capitalize the permanent fund. This is an entirely public IP3, making the IP3 approach separable from private road operation. ${ }^{5}$

However, the IP3 has numerous benefits. By converting economic value released by road pricing into annual dividends for citizen-owners, it garners widespread support for that road pricing. It combines the benefits of road pricing with those offered by a legally-protected permanent fund and with private participation in infrastructure, such as improved operation and maintenance. Pricing transportation facilities through an IP3 provides additional investment for aging, congested transportation facilities in an era of constrained public budgets. The very existence of a permanent fund gives citizen-owners a tangible stake in accurately pricing, properly maintaining, and efficiently operating their transportation infrastructure. Citizens will feel a closer connection to their infrastructure if they receive direct payments from the value it creates for consumers, which will encourage them to take a greater interest in their infrastructure's maintenance and operation. Moreover, dividend payments from fund investment income to the infrastructure system's citizen-owners ameliorate concerns regarding potential misuse of lease proceeds. Dividend payments also reduce the risk of using large upfront payments to fund projects that may have short-term political appeal but do not enhance long-term social welfare. Cash from annual dividends is likely to generate more citizen support than does the mandated spending associated with many real-life P3 projects (Perloff, 2011). For example, some proceeds from the Chicago Skyway concession lease were used for non-transportation purposes, which resulted in criticism of the agreement (Buxbaum and Ortiz, 2007).

Finally, private sector participation incentivizes more-efficient provision of transportation systems through life-cycle asset maintenance and lower toll collection costs. ${ }^{6}$ Importantly, the IP3 approach does not divert toll revenue from use on a facility to capitalize the permanent fund. Instead, the

\footnotetext{
${ }^{5}$ We do not advocate for this approach (selling bonds) because it disallows competitive bidding in the size of the upfront payment. There are other benefits of private participation, such as enhanced ability of the private sector to assess profit opportunities. However, a full discussion of these issues is outside the scope of this paper. See e.g., Geddes (2011). ${ }^{6}$ However, the private sector might have incentives to provide a lower quality service, especially for a short-term contract (De Bettignies and Ross, 2004).
} 
IP3 approach returns economic value embedded in currently un-priced infrastructure assets to its citizenowners. ${ }^{7}$ The concession contract might (should) require that at least part of on-going toll revenue be used to operate and maintain the facility in question. In the next section, we describe how the social welfare effects of adopting the IP3 approach can be assessed within a modeling framework.

\section{Methodology}

\subsection{Benchmark Modeling}

A standard transportation planning model for Fresno, California serves as our basic model. We modify that model to simulate the behavior of transportation users under alternative IP3 schemes. Figure 1 shows the major models (i.e., analytical problems) considered here. At the higher decision-making level, policy makers employ two basic objective functions for transportation system operation: transportation system (i.e., congestion) cost minimization and toll profit maximization. These objectives correspond roughly to public and private road operation, respectively. The system cost minimization problem minimizes a monetary combination of total travel time, total fuel consumption costs, and total emissions costs over a transportation system with toll rates $\left(\tau_{i j}\right.$ 's) as the decision variable. This is similar to the second-best pricing problem in economic studies (e.g., Verhoef, 2007). It is an important problem to consider because policy makers may use system-optimal rates as the basis for capping tolls set by private concessioners. The cost-minimization problem for the system is:

$$
\underset{\tau_{i j}}{\operatorname{Min}}\left(\left(\sum_{i-j}\left(x_{i j}^{*} \cdot t_{i j}\left(x_{i j}^{*}\right) \cdot \beta\right)\right)+\left(\sum_{k} \sum_{i-j} \gamma_{k} \cdot \lambda_{k}\left(\frac{L_{i j}}{t_{i j}\left(x_{i j}^{*}\right)}\right) \cdot L_{i j} \cdot x_{i j}^{*}\right)\right)
$$

where $x_{i j}^{*}$ is the user equilibrium flow, $t_{i j}\left(x_{i j}^{*}\right)$ is the travel time function for each link $i-j, \beta$ is the value of time (VOT) for average users, $\gamma_{k}$ is the unit price of emission or fuel type $k$ in terms of time, and $\lambda_{k}$ is the amount of emissions or fuel factor $k$ in terms of speed. The first term represents total travel time in monetary terms, while the second term calculates total fuel consumption and emissions costs. Rouhani and Niemeier (2014b) provide background on how to incorporate emissions and fuel costs into these models.

An argument could be made against the use of Equation 1, since the objective function performs properly only if $\mathrm{O} / \mathrm{D}$ demand is fixed. Otherwise the solution is to choose very high toll rates and enforce zero traffic flows (and consequently induce zero congestion costs). However, very high toll rates on a few roads could in fact work against the congestion mitigation objective. When applying very high toll rates, total travel demand will not decrease dramatically for an urban network with so many alternative paths/modes. Alternatively, traffic spillover effects will be immense, as shown in our results for the monopoly case in Table 2 below. Additionally, social welfare reductions from inducing lower travel demand could be relatively small (see Table 4). Therefore, this objective function performs well in optimizing the social system-wide congestion level.

We address another problem: suppose a private firm $n$ solves for the profit maximization problem to determine the optimal toll rate. Profit equals toll revenue or $\tau_{i j} . x_{i j}^{*}(\bar{\tau})$ minus toll collection

\footnotetext{
${ }^{7}$ Economic rents realized from road concessions are likely to be largest on congested urban systems.
} 
cost or $C F_{n, i j}$. Toll rates may be capped as required by $\mathrm{P} 3$ contracts (Equation 3), which can affect the optimal toll rate and thus the realized profit:

$$
\underset{\tau_{i j}}{\operatorname{axx}} \pi_{n}=\sum_{(i, j) \in F_{n}}\left(\tau_{i j} \cdot x_{i j}^{*}(\bar{\tau})-C F_{n, i j}(\bar{\tau})\right)
$$

$$
\text { s.t. } \tau_{i j} \leq \tau_{i j}^{\prime}
$$

where $\bar{\tau}$ is the vector of tolls comprised of $\tau_{i j}$ 's-tolls on each link $(i, j)$ - which are capped by $\tau_{i j}^{\prime}$ 's (as the upper limit for toll rates). ${ }^{8}$

The profit maximization model can be extended by considering more than one profit-maximizing firm. This more-complex model must make an assumption about firm interactions. Considering the Bertrand-Nash (B-N) equilibrium, we assume that non-cooperative behavior prevails (Rouhani et al., 2013a). This means that each firm ( $r$ ) develops a response function based on its first-order (F.O.) conditions and determines its own toll rate based on the best response to other firms' $(s$ 's) toll rates $\left(\bar{\tau}_{l m}\right.$ 's):

$$
\text { F.O. } \rightarrow \tau_{i j}^{*}=f\left(\bar{\tau}_{l m}\right), \quad \forall(i, j) \in F_{r},(l, m) \in F_{s}, s \neq r
$$

All of the above models use a modified version of the user equilibrium (UE) problem to determine users' choice in reaction to the various toll schedules applied. The modified UE assumes that the general cost of travel (tolls + time) drives users' choice rather than time only, and that origin/destination (O/D) demand is iteratively updated (reduced) considering the new (higher) general costs of travel, which include a monetary combination of time and tolls for each O/D. The output of the modified UE problem is an equilibrium (future) traffic flow pattern, which will be used to determine system travel costs (time, emissions, and fuel consumption), and toll system profits and costs (projected traffic, revenue, and toll collection costs). ${ }^{9}$

Fig. 1 General modeling framework.

The model can also simulate a situation where some roads are tolled (publicly) with the goal of improving system performance, while other (privately-run) roads are tolled to raise profits. The complex interactions between private and public (and even private and private) roads result in an NP hard combinatorial optimization problem. Instead of optimizing the ownership structure, we solved the problem by considering several scenarios, as shown later in Table 1.

\footnotetext{
${ }^{8}$ It can be shown mathematically that profit maximization and cost minimization problems result in the same solution. However, in our study, the profit maximization problem maximizes the profits from toll collection on few roads, but the system-cost minimization minimizes the transportation system travel costs (total travel time, total fuel consumption, and total emissions from the whole system) over all roads, excluding toll costs. These two problems are different in their objective functions' general form and also in the facilities with which they are concerned (a road(s) versus a transportation system as a whole). Therefore, the two problems do not yield the same outcome.

${ }^{9}$ For detailed information about the modeling approach in this study, see Rouhani and Niemeier, (2014a); Rouhani et al., $(2013 a$ and $b)$.
} 


\subsection{Social Welfare Analysis Framework}

Suppose government considers whether or not to implement tolling on a transportation facility (and to use a public or private IP3). The social welfare gain or loss from those decisions should be compared to the public-sector alternative (PSA). In general, the change in total social welfare is the sum of the change in consumer surplus, producer surplus, government surplus, and employee surplus. All components are usually measured in present value (Boardman and Vining, 2010). A P3 project should be implemented when it improves total social welfare relative to the PSA.

Under an IP3, consumer and producer surplus are the welfare of transportation system users and private sector profits, respectively. Employee surplus is measured by new salaries paid to toll collection agency employees (a portion of toll collection costs). Government surplus is realized from its assigned share of concession payments. In addition to these commonly used components, an IP3 social welfare analysis must include a term for the welfare of residents or the infrastructure's citizen-owners.

Residents may of course also be transportation system users. Because of the difference in level of usage and because of the importance of residents (i.e., citizens) to the political process, we differentiate between residents and users. That distinction requires a more detailed social welfare analysis. However, it should be done carefully to avoid double-counting the benefits and costs of users and residents.

We assume a regional equilibrium for IP3 welfare analysis in which the benefits and costs to those outside urban boundaries will not be counted. Finally, the welfare of stakeholders under an IP3 approach is compared to the no-tolling alternative (NTA) or the do-nothing case. The total social welfare change resulting from IP3 implementation $(\Delta W)$ is:

$$
\begin{aligned}
& \Delta W_{I P 3-N T A}= \\
& \quad \delta_{U} \cdot \Delta U W_{I P 3-N T A}+\delta_{P} \cdot \Delta P W_{I P 3-N T A}+\delta_{G} \cdot \Delta G W_{I P 3-N T A}+\delta_{E} \cdot \Delta E W_{I P 3-N T A}+\delta_{R} \cdot \Delta R W_{I P 3-N T A}
\end{aligned}
$$

where $\Delta U W$ is the users' welfare change, $\Delta P W$ is the private sector's welfare change, $\Delta G W$ is the government's welfare change, $\Delta E W$ is the employees' welfare change, and $\Delta R W$ is the residents' welfare change. The parameters $\delta_{U}, \delta_{P}, \delta_{G}, \delta_{E}$, and $\delta_{R}$ are the welfare weights. These parameters should be set equal to one based on the allocative efficiency criterion (Weimer and Vining, 2009) when conducting a normative evaluation. One critical step is deciding which group of stakeholders should enter the analysis, and thus whose benefits and costs should be counted. For example, users from outside the region might not have standing to be included, so their benefits and costs may be omitted from a regional analysis (Boardman and Vining, 2012).

Figure 2 categorizes the main factors that affect the welfare of each stakeholder type in an urban environment. The users' welfare change is the sum of (i) the average amount of tolls paid by users; (ii) the change in private travel costs (time and fuel) other than tolls, since the transportation system may become more or less efficient as a result of the applied toll scheme (Barr, 2004); and (iii) the decrease in users' welfare because of the induced change in travel behavior that creates disutility; e.g., some users might decide not to travel or to take public transportation because of higher tolls. In addition to those factors, users can benefit from improvements in transportation systems resulting from the added funds available to the public sector. However, such benefits may be negligible for an IP3 that allocates a large portion of toll profits to residents rather than spending it directly on transportation infrastructure. We therefore do not consider such improvements in our analysis. 
Fig. 2 Social welfare factors for each stakeholder type.

The private sector is assumed to maximize profits only. The private sector's profits are determined by the share of profits they would receive (or profits from tolls minus how much the private sector must pay to the public sector) and by travel demand risks. The government's welfare change is from the profits of publicly-tolled roads, as well as their share of the profits of P3-tolled roads. Finally, residents play a key role in selecting P3 projects, so benefits to them are likely to be a major driver for P3 project implementation. Residents' welfare change can be measured by $(i)$ dividends paid to each citizen (household) of the region out of the permanent fund; and (ii) the changes in the criteria pollutant and the $\mathrm{CO}_{2}$ emissions level, based on their health-related costs. ${ }^{10}$ In addition, residents could be better off through improvements in the urban system since profits from P3 projects could be used for improving their urban environment without improving the transportation system. However, we assume that profits will not be spent on urban system improvements.

The inclusion of profits from tolls in our social welfare analysis differs from assumptions in previous road pricing studies (e.g., see Prud'homme and Bocarejo, 2005). Toll profits in those studies are transfers of money from one group to another and are thus excluded from the analysis. This simplifying assumption is misguided for three reasons. First, the weights on different stakeholders' welfare might be different; e.g., the benefits to residents (through dividend payments from tolling profits) might be assigned a greater weight relative to the costs to users (based on the amount of toll paid). Second, the benefits and costs to users from outside the region (the amount of tolls they pay) should not be counted. Third, profits from tolls can serve as a guide for transportation infrastructure investment, thus reducing the scope for misallocation of resources to unprofitable projects.

Toll collection costs and their impact on employee surplus should be considered in our analysis for the same reasons. We omit employee surplus resulting from toll collection costs because: $(i)$ a part of toll collection costs are used for capital and operating costs other than payments to employees and should not be considered in employee surplus; and (ii) the employees' surplus from tolling should be compared to other sources of transportation finance (taxes) since higher spending on tolls could result in lower taxes paid.

Finally, our analysis focuses only on average effects on all stakeholders. Welfare effects are not homogenous across different user groups, for example. Some users might pay more tolls and waste more time and fuel because of driving on more congested roads than before, while others might pay no tolls and benefit from better system performance on specific parts of the system where they drive more frequently. A more detailed analysis on different users' groups (potentially a zonal analysis, which we leave for future work) is required to address such equity implications.

\subsection{Assumptions}

The major assumptions for our analysis are as follows:

- The Fresno transportation planning model is a static, deterministic, single-user equilibrium model (Sheffi, 1984). Since we plan for an uncertain future, real-time prices and real-time demand analyses (a dynamic model) are very complex to estimate. Although a multi-user equilibrium is required for

\footnotetext{
${ }^{10}$ The benefits of GHG reduction affect everyone globally, and the reduction does not offer benefits to the residents of Fresno only. However, since the benefits are more relevant to residents rather than any other stakeholders, we did not assign the benefits to another stakeholder group. In conclusion, residents benefit from lower GHG emissions, as well as other people in the world. In fact, emissions benefits will be leaked to others as co-benefits of IP3 schemes.
} 
analyzing tolling schemes, large-scale models (like the Fresno model) do not cover multi-class features due to their complexity.

- To transform time into monetary cost, we assume an average value of time (VOT) for each user of $\$ 14 /$ hour. This value is assumed to be slightly lower than the average wage of $\$ 16.79$ per hour for Fresno (Schrank et al., 2012). Based on the applied average load factor of 1.4 persons per vehicle, the VOT for each vehicle will be \$20/hour $(14 \times 1.4)$.

- Using the EMFAC-2011 model (CARB, 2013), the emission factors ( $\lambda_{k}$ in Equation 1) are calculated based on the VMT-weighted averages of 2030 emission factors of different vehicle classes at each speed level. Base unit emissions and fuel cost parameters are assumed as follows: $\$ 25 /$ ton of $\mathrm{CO}_{2}, \$ 250 /$ ton of CO, $\$ 7,000 /$ ton of $\mathrm{NO}_{\mathrm{x}}, \$ 3,000 /$ ton of TOG, $\$ 30,000 /$ ton of $\mathrm{PM}_{10}$, $\$ 300,000 /$ ton of $\mathrm{PM}_{2.5}$, and $\$ 4$ /gallon or $\$ 1.06 /$ litter of gasoline (Wang et al., 1994; McCubbin and Delucchi, 1999; AEA Technology Environment, 2005).

- Travel costs other than time, fuel, and emissions (e.g., accidents), are neglected in our analysis because of the complexity of estimating their social welfare effects.

- A flat (constant) mileage $(\mathrm{km})$-based toll rate is applied on a whole road (consisting of various segments) for all scenario cases. However, the toll rate could differ for each time period (temporal variation or peak vs. off-peak prices).

- We assume that toll rates set in P3 contracts remain constant over time. However, in many real-life P3 contracts, the toll rate increases at the Consumer Price Index (CPI), inflation rate, and/or nominal GDP (Bel and Foote, 2009).

- The operating and capital costs of collecting tolls are based on the average estimated cost of two private toll roads: Toronto 407 and Dulles Greenway. Based on the Balducci et al. study (2011) for North American tolled roads, the operating cost is assumed to be $\$ 0.2$ per transaction for private systems and $\$ 0.24$ per transaction for more costly publicly run systems. However, some studies have shown that private provision does not systematically result in lower costs (Bel and Warner, 2008; Bel et al., 2010). Nevertheless, scale or learning economies that cannot be reached by government could ensure lower unit costs of private services (De Bettignies and Ross, 2004). To further analyze the assumption about lower operating costs for private systems, we also relax the assumption in the sensitivity analysis section and consider various ratios of public-to-private system operating costs.

- Considering a 30-year payback period and a 6\% discount rate, the annual average capital cost per mile is $\$ 1.2$ million ( $\$ 0.75$ million per $\mathrm{km}$ ) for highways and $\$ 1.5$ million per mile ( $\$ 0.93$ million per $\mathrm{km}$ ) for arterials because arterials have a larger number of access points.

- Future profits are discounted using a discount rate and demand risk factor combination. The discount rate is assumed to be $6 \%$ for the base case. The demand risk factor (risk mark-up) is used to reflect uncertainties in future toll revenue. It starts at zero and rises to 4 percent in 40 years. We also examine the results considering a higher demand risk of $10 \%$ in Table 6 . In addition, we assume that the profits from $\mathrm{P} 3$ projects (or the corresponding upfront payments) would be distributed among the stakeholders as follows: $10 \%$ to government, $30 \%$ to the private sector, and $60 \%$ to residents. Note that the profit shares are important policy decision variables to be determined. However as we will discuss in Table 5, changes in these shares cannot affect overall social welfare.

- Users are not categorized into inside (with standing) versus outside of the region (without standing). In fact, benefits and costs are calculated on average for all users.

- The transaction costs of P3 contracts are assumed to be negligible. Our rationale is that the profits are collected during a relatively long period of time while the P3 contract negotiation is a one-time cost. 
- We did not consider delays in delivering (and operating) an infrastructure facility, which is common for the public provision of transportation services. Provision of a service on schedule is a major benefit of implementing a P3 approach, and a complete social welfare analysis should have included such benefits (costs).

- The welfare weights ( $\delta$ 's in Equation 5) are set equal to one. However, we examine deviations from the base weights in the sensitivity analysis section.

In addition to the above-mentioned basic parameters, we conduct a sensitivity analysis on some of the major parameters in the results section. The sensitivity analysis captures the impact of allowing the parameters to deviate from assumed basic parameters.

\section{Case study}

As mentioned before, our application is to Fresno's transportation system. The City of Fresno is located in Central California. Alternative estimates report a population of between 300,000 and 510,000 for the city assuming different boundaries. Metropolitan Fresno has a much higher population: about 1.1 million people (City of Fresno Website, 2014). Our intention is not to suggest that Fresno is an ideal place to implement an IP3. Our goal is to show how, using a travel demand model for a large metropolitan area, we could provide the estimates required to undertake a complete social welfare analysis.

We use Fresno's transportation planning model as our lower-level model to simulate users' behavior. As shown in Figure 3 below, we selected seven segments of roads transecting the urban area, including four highways: SR168, SR41, SR180, and SR99; and three arterials: Shaw, Shields, and Blackstone, as candidates for our concession projects. The selected roads' main features can be found in Rouhani et al. (2013a).

Fig. 3 Road network of Fresno, California, with the candidate roads. (Source: Transportation planning model, city of Fresno)

\section{Results}

We begin this section by investigating different sets of decisions (i.e., ownership structures) required for a thorough social welfare analysis of alternative IP3 schemes. Then a systematic social welfare analysis is developed to address the effects of these schemes on the benefits and costs to major stakeholders. Finally, we conduct a sensitivity analysis on several key parameters to examine their impact on results.

\subsection{Alternative Scenario Cases}

Table 1 describes the main features of various scenarios cases. Case 1 represents an unlimited profitmaximizing case for one of the highways (Highway No.1-SR 168). Case 2 sums up individual private ownership of each candidate road; i.e., each road is concessioned separately (only one private road), but the results are reported together. In fact, Case 2 is a combination of seven scenario cases, and its anticipated total profit is the summation of profits from all individual private roads. Cases 3 and 4 simulate the ownership of all the candidate roads by one profit-maximizing firm (monopoly) and by separate profit-maximizing firms (oligopoly). 
Table 1 Main features of alternative schemes under consideration

The corresponding system-optimal scenario case, for which all roads are tolled to minimize system cost, is (Case 5), which usually implies implementing a publicly-operated tolling scheme. Note that Case 5 (or similar pricing methods) does not necessarily represent an IP3 scheme since it might not be profitable and might not be able to provide dividends to residents. Case 6 represents the best twoprivate-roads combination to maximize profits while also reducing congestion by capping toll rates (see Equation 3); Highways No. 2 and No. 4 are concessioned but with limited tolls, and the tolls were found using a heuristic approach. Finally, Case 7 represents mixed public/private operation where Highway No.1 is operated by the public sector to minimize system costs without considering its profits, and Highways No. 2 and No. 4 are operated by the private sector to maximize profits (the best two-privateroads combination), but with toll caps (i.e., toll ceilings). In fact, Case 7 is an extension of Case 6 where a public road is added to improve system performance (a mixed-operator solution). We use a heuristic approach to find the solution for each case. For more information about the approach, refer to Poorzahedy and Rouhani (2007) and Madani et al. (2014).

Prior to providing a detailed social welfare analysis, we examine the overall impacts of applying the scenario cases discussed above. Table 2 reports hourly revenues, costs, and profits for both peak and off-peak periods. Table 2 also reports changes in total system-wide travel costs (other than tolls) of the transportation system as a result of applying those tolling schemes.

From the private sector perspective, competing with priced (especially private) roads is preferable (profitable) to competing with the public and free-of-charge roads. The reason is that most drivers tend to choose the free road over the toll (private) road, even with if it is more congested. Moreover, a private firm does not want to compete against a government firm that may depress tolls in response to political pressure or in consideration of lower social optimal rates. Therefore, P3 candidate projects should be analyzed and evaluated together. Implementing P3 projects together provides much higher profits for the private sector and consequently yields greater upfront concession payments from private sector bidders. As shown by the difference between Case 2 and Cases 3 and 4, the simple summation of the profits of candidate projects implemented individually and not together $(\$ 116.4$ million) is lower than the profits made through leasing all seven P3 candidates together ( $\$ 136$ million or $\$ 120$ million). In addition, applying these projects together has important effects on the transportation system's overall travel costs. Therefore, a comprehensive analysis of an IP3 approach should definitely examine projects (roads) together and even examine the optimal order (i.e., timing) of implementing these projects.

Table 2 The overall outcomes of alternative schemes

Another observation is that the system-cost-minimization (publicly run or Case 5) tolling scheme would be costly (negative profits of $\$ 133$ million because of high toll collection costs), but this (public) scheme could be employed to drastically improve system performance. The major reason for the negative profits is that the system-optimal prices are generally low in order to avoid spillovers to other un-priced roads, and the resulting revenue is lower than toll collection costs. On the other hand, although the profit-maximizing cases (Cases 3 and 4) result in substantial profits, they dramatically increase overall system travel costs. As shown in Table 2, the system-optimal case (Case 5) saves \$226 million of travel costs while the profit-maximizing cases result in a $\$ 400$ million annual increase in travel costs 
(monopoly, Case 3), mainly in the peak periods and by diverting traffic from concession roads to highly congested un-tolled roads.

However, the two extreme cases of system optimization and profit maximization usually fall dramatically short of the opposite goals of raising profits and improving system performance, respectively. A successful P3 project raises profits significantly and simultaneously reduces transportation system travel costs. Neither profit maximization nor system cost minimization should be policy makers' sole targets. Under Case 7, which focuses on a combination of congestion reduction and profit-making, the public sector runs a costly tolling system on one road, not only to improve quality of service but also to potentially boost profits on two private roads. The latter objective provides greater profits for both government and residents. As shown in Table 2, Case 7 raises $\$ 45$ million in toll revenue and decreases travel costs by $\$ 170$ million annually (Table 2).

\subsection{Social Welfare Analysis}

Using the framework described in Section 3.2, we estimate the benefits and costs of using each Investment $\mathrm{P} 3$ approach relative to the do-nothing case. Table 3 reports net benefits as well as details about the annual revenues, costs, and profits of various scenarios for two major stakeholders: government and the private sector. Government's profits are from two major sources: (1) 10\% of P3 projects' profits; and (2) profits from implementing publicly run toll systems. We assume that a privately run tolling system is used in place of a publicly run tolling system as long as the tolling system is profitable. Therefore, public systems result in negative profits for government (costs > revenues) in nearly all cases. Nevertheless, in practice, a public tolling scheme could also raise profits.

Table 3 The government and private sector gains and losses under different scenario cases

Government might not seek the highest social welfare. Politicians may maximize political benefits by raising greater profits and lowering current taxes or providing higher dividends to residents. Based on the economic theory of regulation (Boardman and Vining, 2012), the tendency to seek political benefits may lead policy makers to choose profitable $\mathrm{P} 3$ projects that do not necessarily improve overall social welfare, specifically system performance. As shown in Table 3, the monopoly and oligopoly cases (Cases 3 and 4, with no toll limit) provide the highest profits from tolling while the same cases drastically lower service quality and overall social welfare (as shown in Table 2).

Table 4 reports annual benefits and costs of the above-mentioned ownership cases for two other major stakeholders (average users and residents). As discussed in Section 3, users' social welfare change includes: (1) average tolls; (2) average change in travel costs other than tolls (time and fuel consumption); and (3) average change in social welfare from travel demand reductions for all users. Based on the rule of half (Rouhani and Niemeier, 2011), the last component quantifies the decrease in social welfare when some users decide not to travel due to higher travel costs associated with tolls. Since Fresno's transportation system does not provide a strong public transportation option to users, we do not consider reductions in users' utility that result from switching from private cars to public systems.

When traffic congestion exists in urban transportation settings, the political benefits of implementing higher tolls (where revenues are partially returned to government or residents) may be aligned with the social welfare goal of a more efficient transportation system (Boardman and Vining, 2012). Private and public goals could be aligned only if travel costs (tolls) increase on most roads 
(routes), and a strong public transportation system exists (Rouhani, 2009). However, in most of our profit-maximizing scenarios (e.g., monopoly and oligopoly), the application of high unlimited tolls on few roads does not improve transportation system performance due to spillover effects onto highly congested roads.

Users usually enjoy the greatest benefits under the system-optimal case (Case 5) since the annual benefits of a more-efficient transportation system (\$482.8) can offset the annual toll costs paid (\$478.9) by average users. Note that as technological improvements decrease toll collection costs over time, system-optimal pricing becomes more and more plausible (i.e., less costly) to society since lower toll collection costs might lead to profitable system-optimal pricing schemes. As expected, the worst cases for users are under the profit-maximizing (oligopoly and especially monopoly) structures since users not only pay high tolls, but system performance declines as well. For instance, users end up paying \$1,502 more per annum under the monopoly case, $\$ 900.1$ of which is from higher time and fuel costs. However, motorists who use the roads more than average will lose more, with many inequality implications because of regional (zonal) and income (VOT) factors. However, when average users are better off, we can achieve a Pareto improvement for most users by rebating toll profits and by transferring utility among users. Applying fees to advantaged users and providing credits (monetary support) to disadvantaged users allows such redistribution (Sprumont, 1990; Kockelman and Kalmanje, 2005).

Residents' social welfare change includes two main components: (1) average changes in emissions costs for all residents; and (2) dividends from the IP3 approach. As shown in Table 4, emissions costs are negligible relative to dividends. Dividends are calculated based on a declining principal (instead of perpetuity) approach, for concession periods of 20 and 50 years, applying a demand risk factor as mentioned in Section 3.3. Our estimated dividends are generally lower than the annual dividends of \$1,000 (to each household) found in the Geddes and Nentchev study (2013) for the Columbus, Ohio region. The main reason for the difference is that we assume that only a small set of all urban roads are tolled as P3 concession roads (only 43 miles or $69 \mathrm{~km}$ in totality).

System-optimal cases work well for average users, but government must pay for the costly toll systems. On the other hand, by using profit maximization cases, government and the private sector can raise substantial profits and be better-off, while travel costs may be dramatically higher and users would be worse-off. The overall goal should be finding a Pareto-optimal solution where all stakeholders (average users, average residents, and the public and private sectors) are better-off than the do-nothing case. Case 7, the mixed ownership scenario case, represents a Pareto improvement. Not only do government and the private sector achieve net benefits of $\$ 1.7$ million and $\$ 14.5$ million, the residents and users are also better-off by $\$ 6.6$ and $\$ 90$ ( $\$ 6.5+\$ 82.9$ with a 20 -year concession) annually, respectively. Case 7 is a Pareto improvement despite the fact that under a similar case (Case 6 in which the same two private roads, not the public road), operate, average users will pay $\$ 170$ more annually. The key to Pareto improvement is to use a mixed-ownership structure where some road segments are tolled privately to raise profits, but other road segments are tolled publicly to improve transportation system performance.

Table 4 Residents' and users' gains and losses under different scenario cases

Table 5 summarizes welfare impacts of applying various scenario cases over a 20-year concession period. Social welfare impacts are reported in terms of net present value (NPV) of welfare 
effects on each stakeholder in millions of dollars, over a 20-year period. The first conclusion from Table 5 is that, with base parameters, the mixed ownership scenario case (Case 7) provides the highest social welfare followed by Case 1 (Highway No.1), Case 6 (two best private roads), Case 5 (system-optimal pricing), Case 4 (oligopoly), and Case 3 (monopoly). ${ }^{4}$ The only positive social welfare change is from the mixed ownership case; all other cases reduce social welfare relative to the no-tolling case. ${ }^{11}$ Note that as we discussed in Section 3.3 (Assumptions), changes in the profit shares assigned to stakeholders (10\% to government, $30 \%$ to the private sector, and $60 \%$ to residents) cannot affect total social welfare unless we also modify welfare weights. Nevertheless, another set of shares might turn a Pareto improvement to a scheme where some stakeholders are worse-off or otherwise. Changes in the shares, however, could not affect our results since the only case with a positive total social welfare change (Case 7) is already a Pareto improvement. For cases with negative total welfare change, modifying shares cannot provide a Pareto improvement.

Table 5 Total welfare over a 20-year concession period

Another important observation in Table 5 is that a system-optimal pricing scheme, which has been traditionally employed in many transportation system analyses, may result in negative total social welfare. Although the system-optimal goal is to improve system performance, toll collection (i.e. transaction) costs can be relatively high in urban environments (due to many entry and exit points) and, as a result, such schemes can reduce social welfare. Ignoring transaction costs is one flaw typical of transportation studies.

\subsection{Sensitivity Analysis}

To provide a reliable social welfare impact analysis, we conduct a sensitivity analysis on several key parameters to assess the robustness of our key findings. Figure 4 shows the changes in total social welfare (in billions of dollars) under different scenario cases when (a) travel demand deviates from its base level by $10 \%$; and (b) the discount rate differs from its base rate of $6 \%$, and is instead $3 \%$ and $9 \%$.

Fig. 4 Sensitivity of total social welfare change with respect to $(a)$ travel demand and $(b)$ discount rate.

As shown in Figure 4-a, under the profit-maximizing cases (Case 3, 4, and 6), an increase in demand results in an increase in total social welfare, relative to the base scenario (shown in Table 5). For the system-optimal case (Case 5), however, an increase in demand reduces social welfare. This difference in outcomes stems from the fact that with an increase in demand, profits will grow, but congestion will intensify.

Under our assumptions, the change in discount rate multiplies the values of social welfare change by a certain ratio since all stakeholders enjoy constant annual cash flows over time, and the only

\footnotetext{
${ }^{11}$ One may argue that the system-optimal case (with all roads being tolled) should provide the highest social welfare, but this is not true in our study for two reasons. First, the system-optimal cases do not account for transaction costs (toll collection costs). So even for the base parameters, they result in negative change in social welfare. Second, for a thorough analysis, we need to analyse the variations in the welfare weights of each group (not necessarily equal weights).
} 
present expenditure in our analysis (the capital cost of toll collection) is negligible relative to other annual values (Figure 4-b). However, in practice, the impacts of discount rate changes are more complex since the cash flows differ over the years of analysis. Discount rates are one of the most important factors in evaluating real-life P3 projects, so a thorough sensitivity analysis is warranted.

The welfare weights ( $\delta$ 's in Equation 5) are crucial for social welfare calculations; a policy analysis should determine whose benefits and costs should be included and in what ratios. Figure 5 depicts the outcomes of changing (a) residents' weight and (b) users' weight. The rationale behind increasing residents' weight is that residents could be viewed as the real owners of the transportation infrastructure. They can also affect the political will to mobilize the process for much-needed fundamental changes in transportation system provision.

As expected, the increase in residents' weight favors more-profitable monopoly and oligopoly cases (Cases 3 and 4). When the profit-maximizing scenarios are implemented, government may gain political benefits by increasing residents' support by providing high dividends, balancing the budget, boosting the private sector's profits, and keeping current fuel (or other) taxes low. However, the overall outcome of the highest social welfare for the mixed ownership case (Case 7) does not change unless very high residents' weights (e.g., 20 in Figure 5-a where all other weights are one) are applied.

Fig. 5 Sensitivity of total social welfare change with respect to $(a)$ residents' welfare and $(b)$ users' welfare.

In addition to increasing residents' weight, policy makers could use a lower users' weight than unity since some users could be foreigners without equal standing in the social welfare calculations. As shown in Figure 5-b, profit-maximizing cases benefit more from a decrease in users' weight. However, using a weight of 0.5 or higher ( $50 \%$ of users of an urban system, at most, might be foreigners), the mixed ownership case still provides the highest social welfare. The Interstate Commerce Clause of the Constitution (Article I, Section 8, Clause 3) prevents state governments from interfering with commerce by using pricing strategies or by tolling interstates; "beggar thy neighbor" would be an example (Commerce Clause, 2013). Therefore, legally, social welfare calculations become more complex than excluding or including users from outside the region.

An average VOT (not a detailed stratified VOT distribution) affects the trade-offs between money (tolls) and time. Under the same traffic flow pattern (which results in the same general travel costs), a higher average VOT will result in higher optimal toll rates (monetary) and consequently higher revenues by a constant ratio. ${ }^{12}$ On the other hand, increasing VOT will boost travel time savings resulting from the tolling scheme (in monetary terms) by a constant ratio. Figure 6 shows how social welfare is affected by deviations in VOT.

\footnotetext{
${ }^{12}$ Let us assume that we have only one road being tolled, and the toll rate is the decision variable. Also, assume that the timeequivalent-cost of each toll rate is $t^{\prime}$. The revenue maximization problem can then be written as: $x^{*}\left(t\left(x\left(t^{\prime}\right)\right)+t^{\prime}\right) * t^{\prime} *$ VOT, where $x^{*}$ is the equilibrium flow pattern (traffic demand), $t$ is the travel time which is a function of traffic flow $x$ (which is self is a function of tolls) $t^{\prime}$, and VOT is an estimate of value of time for average users. In fact, $x^{*}$ represents the equilibrium demand (which is a function of the summation of travel time and toll cost in terms of time), and $t^{\prime} *$ VOT represents tolls in monetary terms. Multiplying these two factors (demand and toll), we reach the profits for each toll rate. As can be seen, VOT acts like a constant multiplier and cannot change the profit-optimal toll rate (in terms of time or $t^{\prime}$ ) since the only effective factor is the time-equivalent-cost of each toll rate or $t^{\prime}$. But VOT will change the profit level by a ratio. This only holds true when we have one group of users (only one VOT).
} 
In most cases, an increase in VOT magnifies the total social welfare both positively and negatively. Increasing VOT will increase profits since users are more willing to pay for better service, and will increase travel costs since time costs are linearly dependent on VOT. Nevertheless, Case 5-the system-optimal case-is an exception to this rule; total social welfare is negative but becomes positive with a $\$ 40$ VOT. For a congestion management case, to reach the system-optimal flow pattern, policy makers need to charge a higher toll; tolls in terms of time-equivalent-costs should be held constant to reach the system-optimal flow pattern, but a higher VOT leads to higher tolls in monetary terms and consequently to higher toll revenues. Meanwhile, toll collection costs remain constant since the optimal traffic flow pattern is fixed. Travel time savings also increase with VOT. Therefore, for a congestion management system, a higher VOT is usually commensurate with a higher social welfare.

Fig. 6 Sensitivity of total social welfare change with respect to value of time (VOT).

We also analyze variations in operating costs of public toll collection systems. For our base case, as discussed in Section 3.3, the operating cost of public systems is assumed to be $20 \%$ higher than that of private systems. Here, we relax this assumption and consider various ratios of public to private systems' operating costs. This assumption affects only Cases 5 and 7 since these are the only cases with public toll roads. Figure 7 shows the effects of the operating cost ratio on social welfare. Variations in the ratio have relatively minor effects on the final outcome; however, the effects are greater for an allpublic system (Case 5, Figure 7-a). Nevertheless, with all operating cost ratios applied, Case 6 again provides the highest change in social welfare.

Fig. 7 Sensitivity of total social welfare change to public-private operating cost ratios for Case $5(a)$, and Case 7

$(b)$.

As the final parameter, we provide a sensitivity analysis on the assumed demand risk of $4 \%$ (refer to Section 3.3 for information how demand risk is applied). Demand risk is an extremely important parameter for our analysis since it greatly affects the estimated profitability of each scenario case. As expected, demand risk needs to be estimated based on characteristics for each case and differs from case to case. However, because of uncertainty in future demand, we need to run a sensitivity analysis. Table 6 reports the estimated dividends under two different demand risks: $4 \%$ and $10 \%$. As can be seen in Table 4 , a higher demand risk can significantly reduce the dividend paid to residents, and its effects are higher for a longer concession period (50 years) since a longer concession period is commensurate with a more uncertain future demand.

Table 6 Dividends under different demand risk rates

We can observe from the figures and the table in this section that all the parameters used for estimations have important impacts on the analysis. This shows the importance of providing a sensitivity analysis on major parameters. Not only should we consider different values for the parameters, but we should also consider different combinations of these values for a more robust analysis. Moreover, we 
should expand the sensitivity analysis beyond the parameters considered in this section to apply, for instance, various fuel costs, population, and land use scenarios.

\section{Conclusions}

In this study, we develop a general social welfare analysis framework that considers the major stakeholders (residents, users, government, and the private sector) for the assessment of the alternative investment public-private partnership (IP3) schemes. Using the framework, we estimate the social welfare change resulting from implementing IP3 alternatives for an urban transportation network. Our overall policy analysis indicates that the IP3 concept creates value by encouraging road pricing through its annual dividend, but that the net value creation comes from the implementation of road pricing. Using a very detailed modeling framework, we demonstrate that economic value cannot be realized from a transportation facility in the form of consumer and producer surplus unless the facility is properly priced. IP3 structures coupled with proper price signals could offer a long-term sustainable funding solution. Therefore, we examined several alternative IP3 schemes and simulated the behavior of users in response to these schemes.

Our social welfare analysis results show that system-optimal schemes (tolls) could decrease total travel costs incurred by average users, but government should pay for the costly toll systems. In contrast, unlimited profit maximization schemes raise substantial profits for government, residents, and the private sector while users incur huge increases in their transportation costs through both toll payments and higher travel time and fuel consumption costs. From a public interest viewpoint, policy makers should search for a Pareto improvement where all stakeholders are better-off. One of our scenario cases, which simulates a mixed private and public tolling scheme with mixed profit maximization and system cost minimization goals, represents a Pareto improvement. In addition, using our base assumptions, the mixed private and public IP3 scheme (Case 7) increases total social welfare by close to $\$ 500$ million over a 20 -year period.

Using sensitivity analysis, we show that changes in major factors such as travel demand level, discount rate, welfare weights, and value of time (VOT) do not affect the ultimate outcome: the mixedtolling scheme provides the highest social welfare unless changes in those factors are extraordinary. However, a decrease in users' weight and an increase in residents' weight seem reasonable since some users are not from the region (they do not have equal standing in social welfare calculations unless because of legal constraints), and residents play important roles in the public acceptance of an IP3 approach.

Our modeling suffers from several simplifications. First, potential improvements in transportation and urban systems are neglected. P3 profits (upfront payments) can be used to improve transportation system performance, but since the IP3 approach assumes that the main portion of P3 profits will be redistributed to residents, we did not account for these potential improvements. In fact, the IP3 approach could be compared to the use of an infrastructure fund that can potentially increase social welfare through improving transportation systems, creating new jobs, and stimulating long-term growth.

Second, our analysis is based on average effects. A more detailed analysis should take the effects on different groups of user/residents into account, especially from an equity perspective. Third, our model simulates a static process, so it fails to capture potential dynamics between different time periods in the long run and the possible difference in annual profits and costs in different years. Fourth, the employed benchmark modeling could be improved by using multi-user equilibrium (Yang and Huang, 
2004) and considering heterogeneity in VOT of users (Small, 2012), more detailed analysis of travel demand uncertainty (Chen and Subprasom, 2007), quantification and optimal allocation of risk (Jin and Zhang, 2011), and more advanced objective functions than abstract profit maximization and system cost minimization. Nevertheless, our modeling framework and our results provide the foundation for future social welfare studies that evaluate transportation $\mathrm{P} 3$ projects.

Finally, our intention is not to suggest that Fresno is necessarily the appropriate place to implement an IP3. We show that how an IP3 scheme can be implemented, what tools/models are needed, and how to apply/formulate a social welfare analysis. As shown by our previous studies (Rouhani and Niemeier, 2011), an IP3 approach (like a P3 approach) can further improve social welfare for a metropolitan area with a strong public transportation system since an IP3 can incentivize the use of more energy-efficient modes while it does not greatly reduce travel demand.

Future work could develop a more in-depth social welfare analysis that will account for the equity effects on different groups of users and residents. In addition, certain types of risks associated with the P3 project delivery should be quantified and considered in the social welfare analysis in greater detail. Finally, the effects on factors outside the transportation sector, such as employment, land use, and work hours, should also be taken into account. With the consideration of such factors along with the potential decrease in insurance and maintenance costs of travel and GHG emissions globally, our proposed IP3 schemes could offer significantly higher benefits than estimated.

\section{Caveat}

The transportation planning model used in this study was employed only for research purposes, and not for developing regional transportation plans or transportation improvement programs. The authors do not obtain financial interests or benefits from the direct applications of this research.

\section{Acknowledgments}

The authors express their special gratitude to anonymous reviewers for their useful suggestions and comments. We also thank the partial funding support from the Regional 2 University Transportation Research Center. 


\section{References}

AEA Technology Environment. 2005. Damages per tonne emission of PM2.5, NH3, SO2, NOx and VOCs from each EU25 member state and surrounding seas. Clean Air for Europe (CAFE) Programme. European Commission. Available at: http://www.cafe-cba.org/assets/marginal_damage_03-05.pdf, (accessed October 2012).

Albalate, D., Bel, G., Fageda, X., 2009. Privatization and regulatory reform of toll motorways in Europe. Governance 22(2), 295-318.

Anderson, D., and Mohring, A., 1996. Congestion costs and congestion pricing for the Twin Cities, Minnesota Department of Transportation, Report MN-RC-96-32.

Arnold, R., Doan, J. Q. and Decorla-Souza, P. 2012. Creating and Funding Multimodal Public-Private Partnership Solutions for Suburb-to-Suburb travel, Paper Presented in the 91st Annual Meeting of the Transportation Research Board (Paper No. 12-0533).

Balducci, P., Shao, G., Amos, A., Rufolo, A., 2011. Costs of alternative revenue-generation systems. National Cooperative Highway Research Program-NCHRP REPORT 689, ISBN 978-0-309-21316-5.

Barr, N., 2004. Economics of the Welfare State. Oxford University Press, New York, USA.

Bel, G., Warner, M., 2008. Does privatization of solid waste and water services reduce costs? A Review of Empirical Studies. Resources, Conservation \& Recycling, 52(12), 1337-1348.

Bel, G., Fageda, X., Warner, M., 2010. Is private production of public services cheaper than public production? A meta-regression analysis of solid waste and water services. Journal of Policy Analysis and Management, 29(3), $553-577$.

Bel, G., Foote, J., 2009. Tolls, terms and public interest in road concessions privatization: A comparative analysis of recent transactions in the USA and France. Transport Reviews, 29(3), 397-413.

Boardman, A., Vining, A. R., 2010. Assessing the economic worth of public-private partnerships. International Handbook on Public-Private Partnerships, Cheltenham, UK: Edward Elgar, pp. 159-186.

Boardman, A. E., Moore, M. A., Vining, A. R. 2010. The social discount rate for Canada based on future growth in consumption. Canadian Public Policy, 36(3), 325-343.

Boardman, A. E., Vining, A. R., 2012. The political economy of public-private partnerships and analysis of their social value. Annals of Public and Cooperative Economics, 83(2), 117-141.

Buxbaum, J. N., Ortiz, I. N., 2007. Protecting the public interest: The role of long-term concession agreements for providing transportation infrastructure. Research Paper No. 07-02. Keston Institute for Public Finance Policy and Infrastructure Policy, University of Southern California.

Buxbaum, J. N., and I. N. Ortiz, 2009. Public Sector Decision making for Public-Private Partnerships: A Synthesis of Highway Practice, Washington, DC: Transportation Research Board, National Cooperative Highway Research Program, Synthesis 391, available at: http://onlinepubs.trb.org/onlinepubs/nchrp/nchrp_syn_391.pdf (accessed August 6, 2014).

Burris, M., Lee, S., Geiselbrecht, T., Baker, R., 2013. Equity evaluation of sustainable mileage-based user fee scenarios (No. SWUTC/14/600451-00007-1). Technical Report No. SWUTC/14/600451-00007-1. Southwest 
Region University Transportation Center. Available at: http://d2dt15nnlpfr0r. cloudfront. net/swutc. tamu. edu/publications/technicalreports/600451-00007-1. Pdf (accessed August 5, 2014).

California Air Resources Board (CARB), 2013. EMFAC model-2011. Retrieved from: http://www.arb.ca.gov/jpub/webapp//EMFAC2011WebApp/MainPageServlet?b_action=view, Accessed January 2013.

City of Fresno website, Available at: http://www.fresno.gov/DiscoverFresno/default.htm, (accessed June 2014).

Chen, A., Subprasom, K., 2007. Analysis of regulation and policy of private toll roads in a build-operate-transfer scheme under demand uncertainty. Transportation Research Part A, 41(6), 537-558.

Commerce Clause, 2013. Available at: http://en.wikipedia.org/wiki/Commerce_Clause\#cite_note-3, (accessed August 2013).

De Bettignies, J. E., Ross, T. W., 2004.The economics of public-private partnerships. Canadian Public Policy/Analyse de Politiques, (2004), 135-154.

Finkelstein, A. 2009. E-ZTAX: Tax Salience and Tax Rates. Quarterly Journal of Economics, MIT Press, 124(3), 969-1010.

Foster, D., 2013. Virginia Supreme Court reverses ruling on tunnel tolls. Virginia Appellate News \& Analysis, Available at: http://www.virginia-appeals.com/media_coverage.aspx?id=223, (accessed August 2014).

Garner, B. A. and Black, H. C. 2009. Black's law dictionary. 9th ed. St. Paul, Minn.: West Group.

Geddes, R. R., 2011, The Road to Renewal: Private Investment in U.S. Transportation Infrastructure Washington DC: AEI Press.

Geddes, R. R., Nentchev, D. N., 2013. Road Pricing and Asset Publicization: A New Approach to Revitalizing U.S. Infrastructure, AEI Policy Brief, Washington, DC: American Enterprise Institute (December 2013), Available at: http://www.aei.org/files/2013/12/10/-road-pricing-and-asset-publicization_12592596596.pdf, (accessed August 4, 2014).

Geddes, R. R., Nentchev, D. N., 2014. From Free to Priced Infrastructure: U.S. Roads and the Investment PublicPrivate Partnership. Cornell Program in Infrastructure Policy working paper.

Gómez-Ibáñez, J., 2006. Regulating Infrastructure: Monopoly, Contracts, and Discretion, Cambridge, Mass: Harvard University Press.

Heald, D., 2003. Value for money tests and accounting treatment in PFI schemes, Accounting, Auditing and Accountability Journal, 16 (3), 342-371.

Johnston, J., 2010. Examining "tunnel vision" in Australian PPPs: rationales, rhetoric, risks and "rogues". Australian Journal of Public Administration, 69 (S1), 61-73.

Kockelman, K. M., Kalmanje, S., 2005. Credit-based congestion pricing: a policy proposal and the public's response. Transportation Research Part A, 39(7), 671-690. Jin, X. H., Zhang, G., 2011. Modelling optimal risk allocation in PPP Projects using artificial neural networks. International journal of project management, 29(5), 591-603. 
King, D., Manville, M., Shoup, D., 2007. The political calculus of congestion pricing. Transport Policy, 14 (2), $111-123$.

Kockelman, K. M., Kalmanje, S., 2005. Credit-based congestion pricing: A policy proposal and the public's response. Transportation Research Part A, 39(7), 671-690.

Madani, K., Rouhani, O. M., Mirchi, A., Gholizadeh, S., 2014. A negotiation support system for resolving an international trans-boundary natural resource conflict. Environmental Modelling \& Software, 51, 240-249.

McCubbin, D. R., Delucchi, M. A., 1999. The health costs of motor-vehicle related air pollution. Journal of Transport Economics and Policy, 33(3), 253-286.

Olson, D. O., O'Brien, J. P., 1990. The great Alaskan money giveaway program. Economic Inquiry, 28(3), 604615 .

Parry, I. W. and Bento, A. 2001. Revenue recycling and the welfare effects of road pricing. The Scandinavian Journal of Economics, 103 (4), pp. 645-671.

Parry, I. W. H., Bento, A. M., 2002. Estimating the welfare effect of congestion taxes: The critical importance of other distortions within the transport system. Journal of Urban Economics, 51(2), 339-365.

Perloff, Jeffrey. M. 2011. Microeconomics (6th Edition) (The Pearson Series in Economics). New York: AddisonWesley.

Poorzahedy, H., Rouhani, O. M., 2007. Hybrid meta-heuristic algorithms for solving transportation network design. European Journal of Operational Research, 182(2), 578-596.

Prud'homme, R., Bocarejo, J. P., 2005. The London congestion charge: A tentative economic appraisal. Transport Policy, 12(3), 279-287.

Rouhani O. M., 2009. Road privatization and sustainability. MIT Journal of Planning, 6, 82-105.

Rouhani, O. M., 2012. Frameworks for Public-Private Partnerships. Ph.D. dissertation, University Of California, Davis.

Rouhani, O. M., Niemeier, D., 2011. Urban network privatization: A small network example. Transportation Research Record, 2221, 46-56.

Rouhani, O. M., Niemeier, D., 2014a. Flat versus spatially variable tolling: A case study of Fresno, California. Journal of Transport Geography, 37, 10-18.

Rouhani, O. M., Niemeier, D., 2014b. Resolving the property right of transportation emissions through publicprivate partnerships. Transportation Research Part D, 31, 48-60.

Rouhani, O. M., Niemeier, D., Knittel, C. R., Madani, K., 2013a. Integrated modeling framework for leasing urban roads: A case study of Fresno, California. Transportation Research Part B, 48(1), 17-30.

Rouhani, O. M., Gao, O., Geddes, R. R., 2013b. Policy lessons for regulating public-private partnership tolling schemes in urban environments. Transportation Policy, 41 (2015), 68-79. 
Safirova, E., Gillingham, K., Parry, I. W. H., Nelson, P., Harrington, W., Mason, D., 2004. Welfare and distributional effects of road pricing schemes for metropolitan Washington, DC. Research in Transportation Economics, 9, 179-206.

Schrank, D., Eisele, B., Lomax, T., 2012. TTI's 2012 Urban mobility report. Texas A\&M Transportation Institute (TTI). The Texas A\&M University System.

Sheffi, Y., 1984. Urban Transportation Networks: Equilibrium Analysis with Mathematical Programming Methods. Englewood Cliffs, N.J., Prentice-Hall.

Small, K. A. 1983. The incidence of congestion tolls on urban highways. Journal of Urban Economics, 13 (1), pp. $90-111$.

Small, K. A. 1992. Using the revenues from congestion pricing. Transportation, 19 (4), pp. 359-381.

Small, K., 2012. Valuation of travel time. Economics of Transportation, 1(1-2), 2-14.

Sprumont, Y., 1990. Population monotonic allocation schemes for cooperative games with transferable utility. Games and Economic behavior, 2(4), 378-394.

Swan, P. F., Belzer, M. H., 2010. Empirical evidence of toll road traffic diversion and implications for highway infrastructure privatization. Public Works Management and Policy, 14(4), 351-373.

Tan, Z., Yang, H., Gu, X., 2010. Properties of Pareto-efficient contracts and regulations for road franchising. Transportation Research Part B, 44(4), 415-433.

Velaga, N. R., Pangbourne, K., 2014. Achieving genuinely dynamic road user charging: issues with a GNSSbased approach. Journal of Transport Geography, 34, 243-253.

Verhoef, E.T., 2007. Second-best road pricing through highway franchising. Journal of Urban Economics, 62 (2), $337-361$.

Vickrey, W. 1992. Principles of Efficient Congestion Pricing - William Vickrey. Victoria: Victoria Transport Policy Institute.

Vining, A. R., Boardman, A. E., 2008. Public-private partnerships eight rules for governments. Public Works Management and Policy, 13(2), 149-161.

Wang, M.Q., Santini, D. J., Warinner, S. A., 1994. Methods of valuing air pollution and estimated monetary values of air pollutants in various US regions. Technical report, Argonne National Lab.

Weimer, D. L., Vining, A. R., 2009. Investing in the Disadvantaged: Assessing the Benefits and Costs of Social Policies. Washington D.C., Georgetown University Press.

Winston, C., Yan, J., 2011. Can privatization of U.S. highways improve motorists' welfare? Journal of Public Economics, 95(7-8), 993-1005.

Yang, H., Huang, H. J., 2004. The multi-class, multi-criteria traffic network equilibrium and systems optimum problem. Transportation Research Part B, 38(1), 1-15. 
Yang, H., Meng, Q., 2000. Highway pricing and capacity choice in a road network under a build-operate-transfer scheme. Transportation Research Part A, 34(3), 207-222.

Yuan, J., Zeng, A. Y., Skibniewski, M. J., Li, Q., 2009. Selection of performance objectives and key performance indicators in public-private partnership projects to achieve value for money. Construction Management and Economics, 27(3), 253-270.

Zhang, L. 2008. Welfare and financial implications of unleashing private-sector investment resources on transportation networks. Transportation Research Record, 2079, 96-108.

Zhang, L., Yusufzyanova, D. 2012. Impact of regulation and network topology on effectiveness of roadway privatization. Transportation Research Record, 2297, 172-180. 


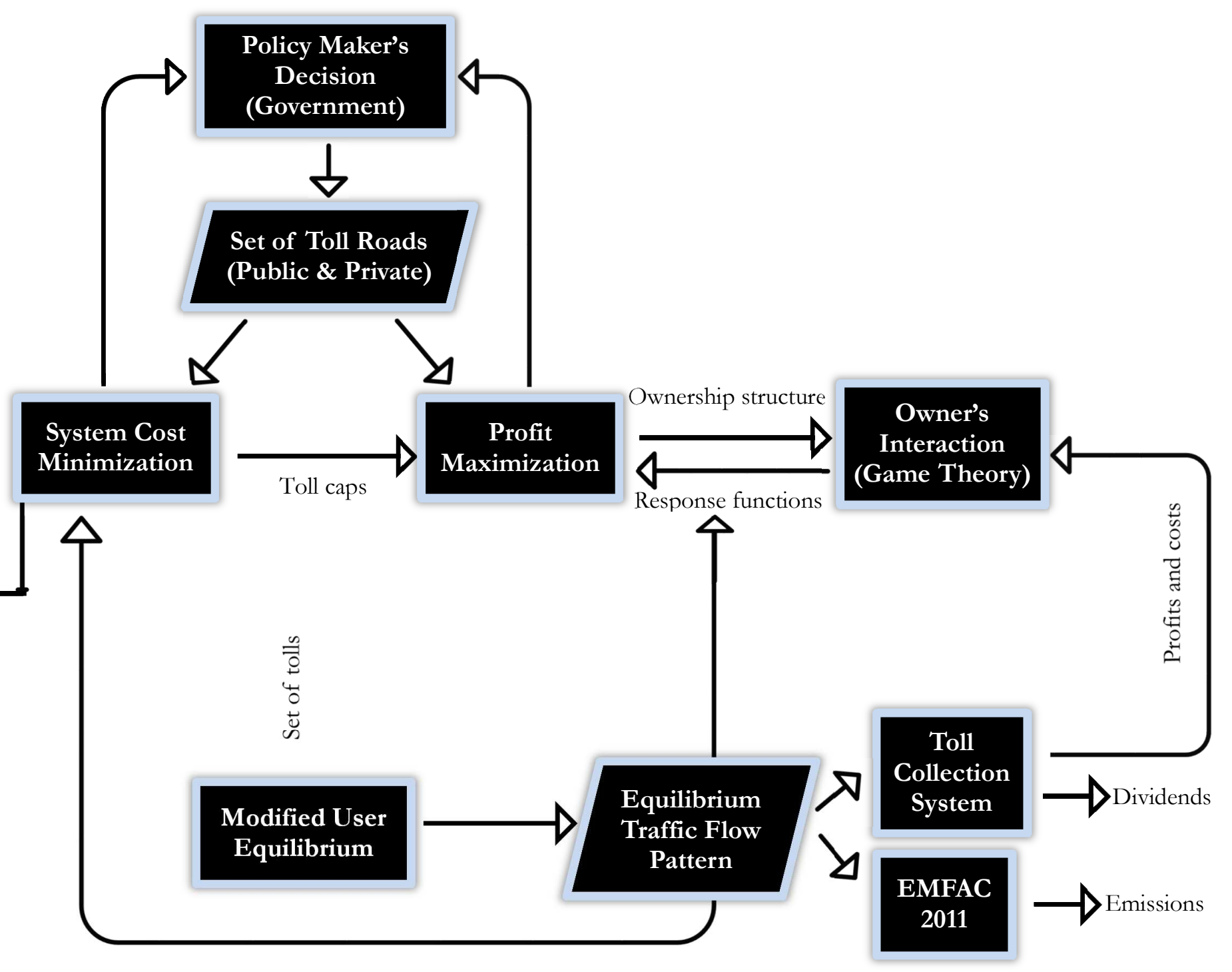

Fig. 1. General modeling framework 


Users' Welfare:
(1) Tolls paid
(2) Change in time and fuel
(3) Change in demand
(*) Improvement in
transportation

\section{Private Welfare:}

Њ

(1) Revenues (tolls)

(2) Costs of toll collection
屯

Government Welfare:

(1) Profits of P3s

(2) Profits of public tolls
Resident's Welfare:

4 (1) Dividends from IP3's (2) Change in emissions

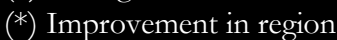

Fig. 2. Social welfare factors for each stakeholder type. 


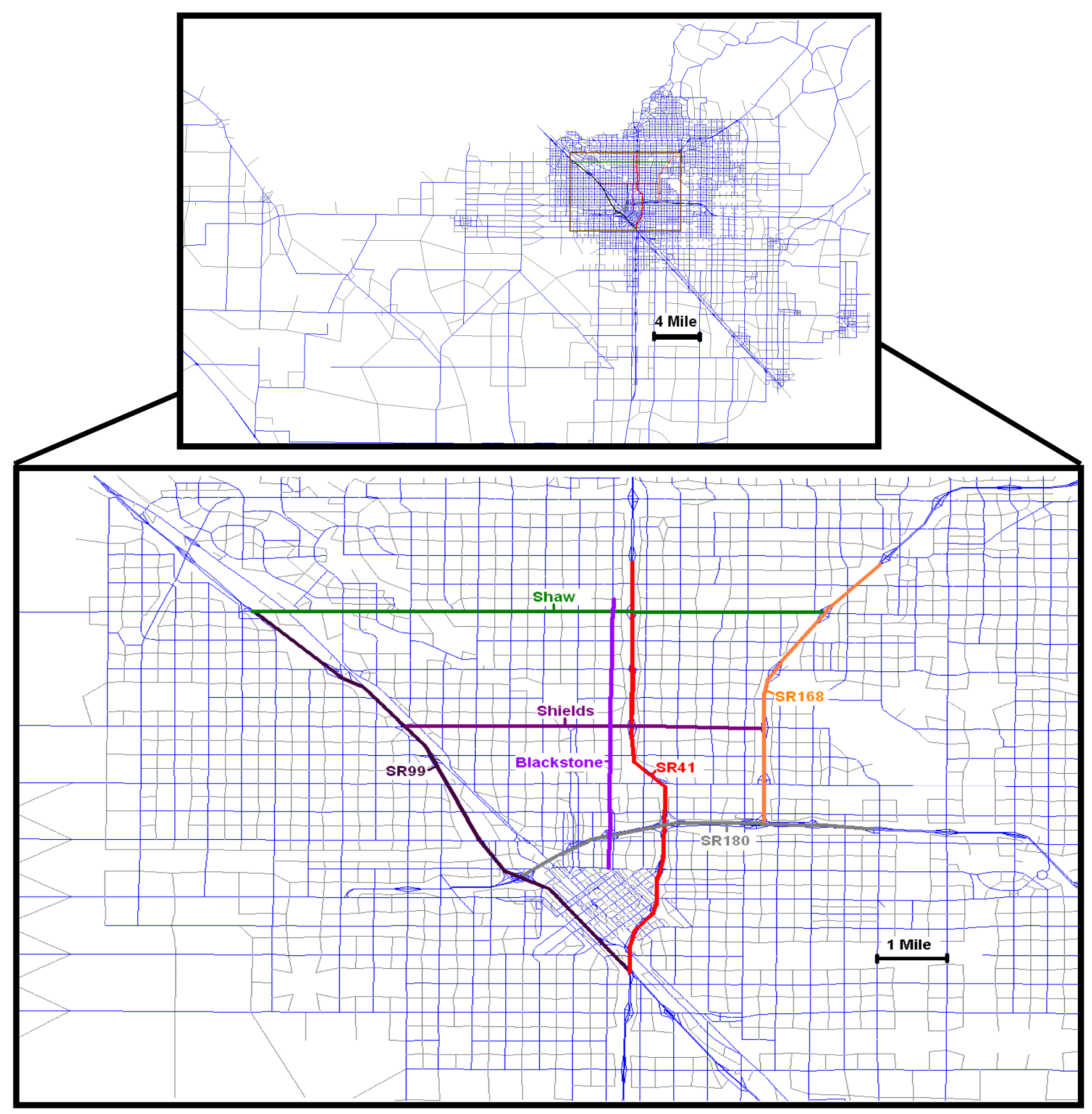

Fig. 3. Road network of Fresno, California, with the candidate roads. (Source: Transportation planning model, city of Fresno) 

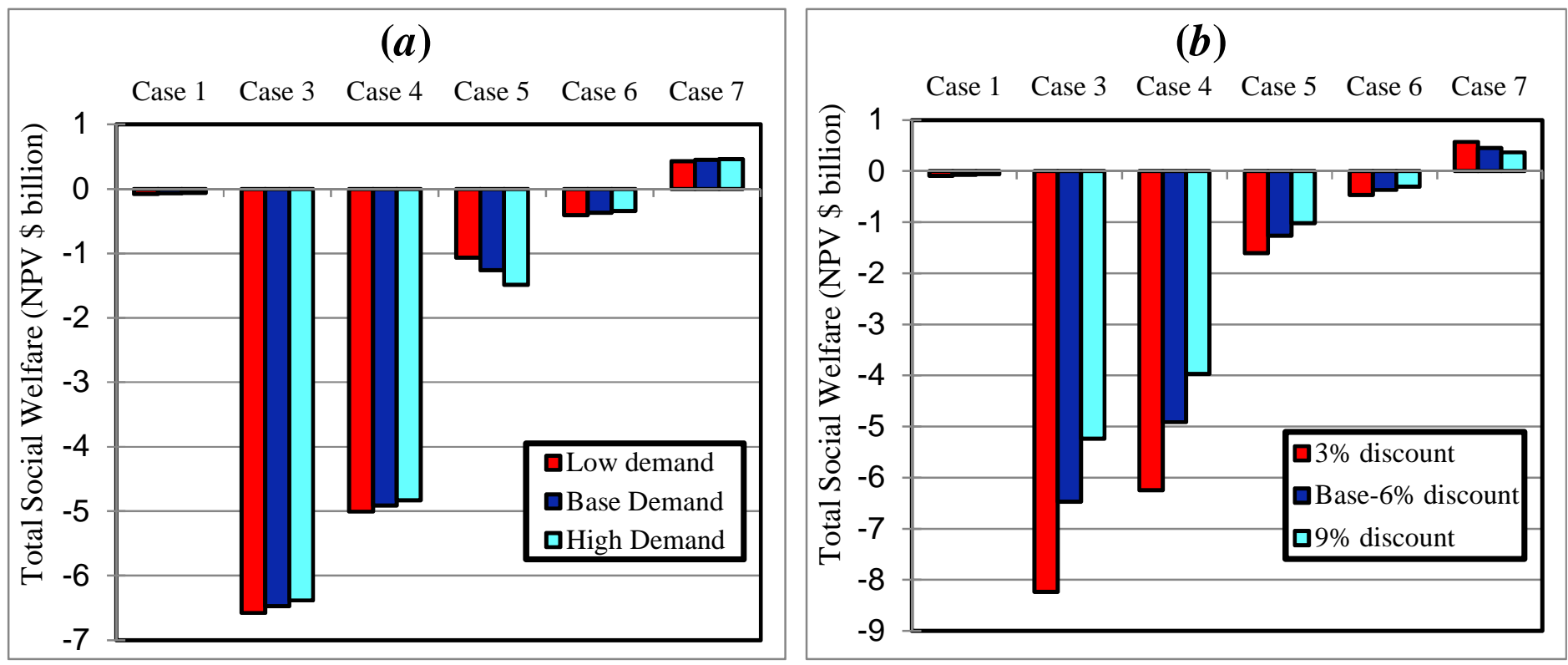

Fig. 4. Sensitivity of total social welfare change with respect to $(a)$ travel demand and $(b)$ discount rate. 

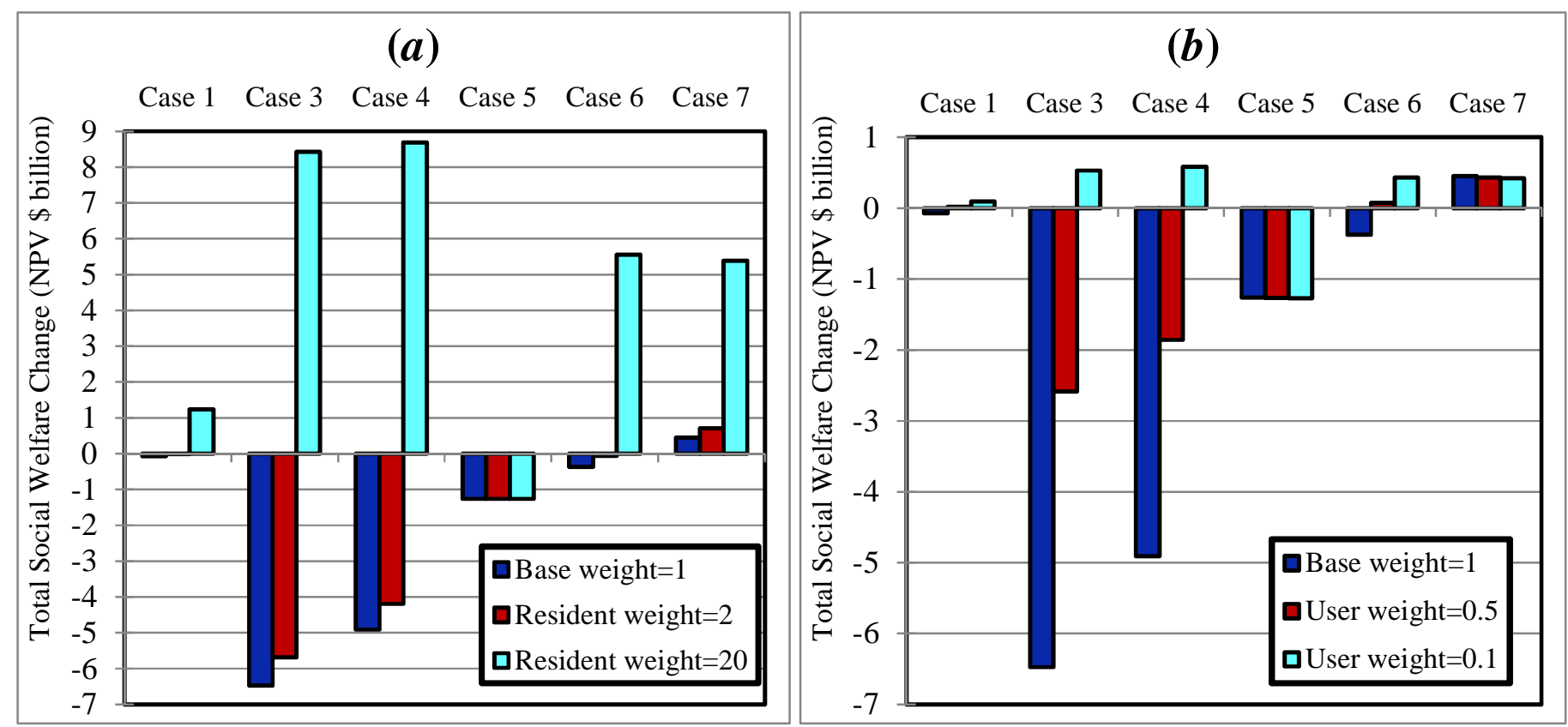

Fig. 5. Sensitivity of total social welfare change with respect to $(a)$ residents' welfare and $(b)$ users' welfare. 


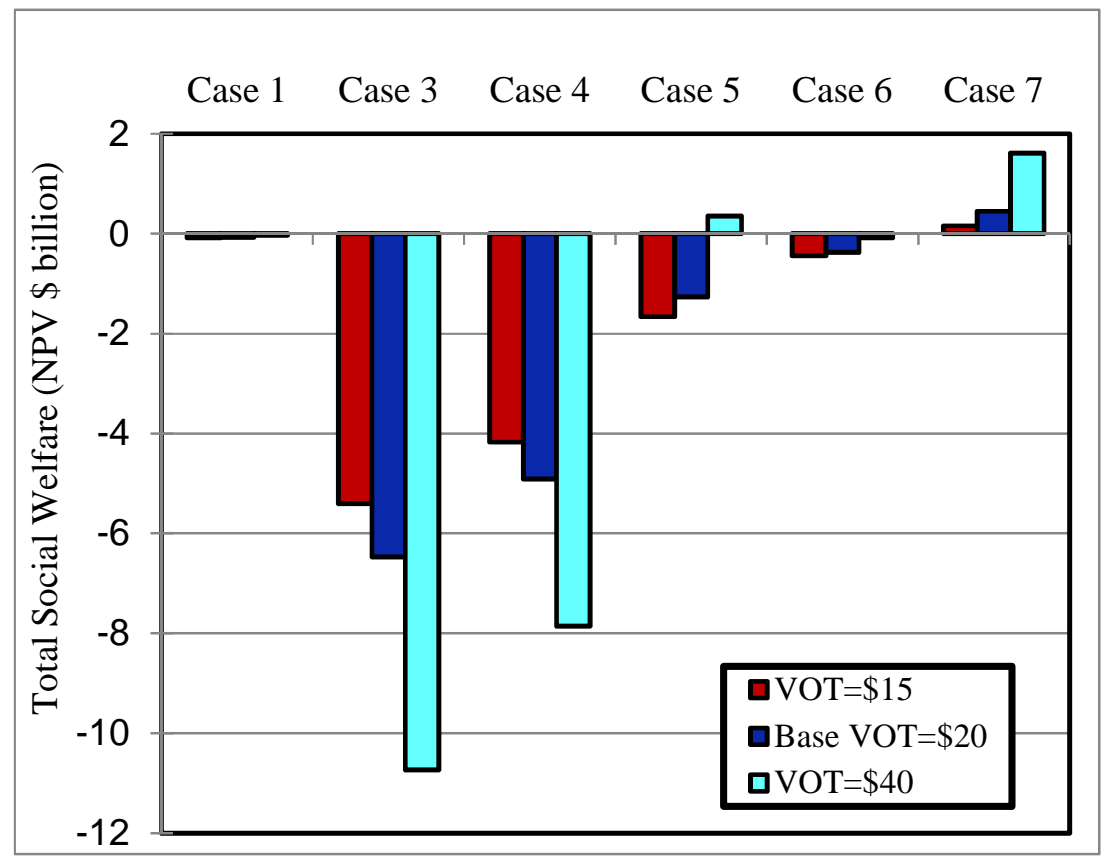

Fig. 6. Sensitivity of total social welfare change with respect to value of time (VOT). 

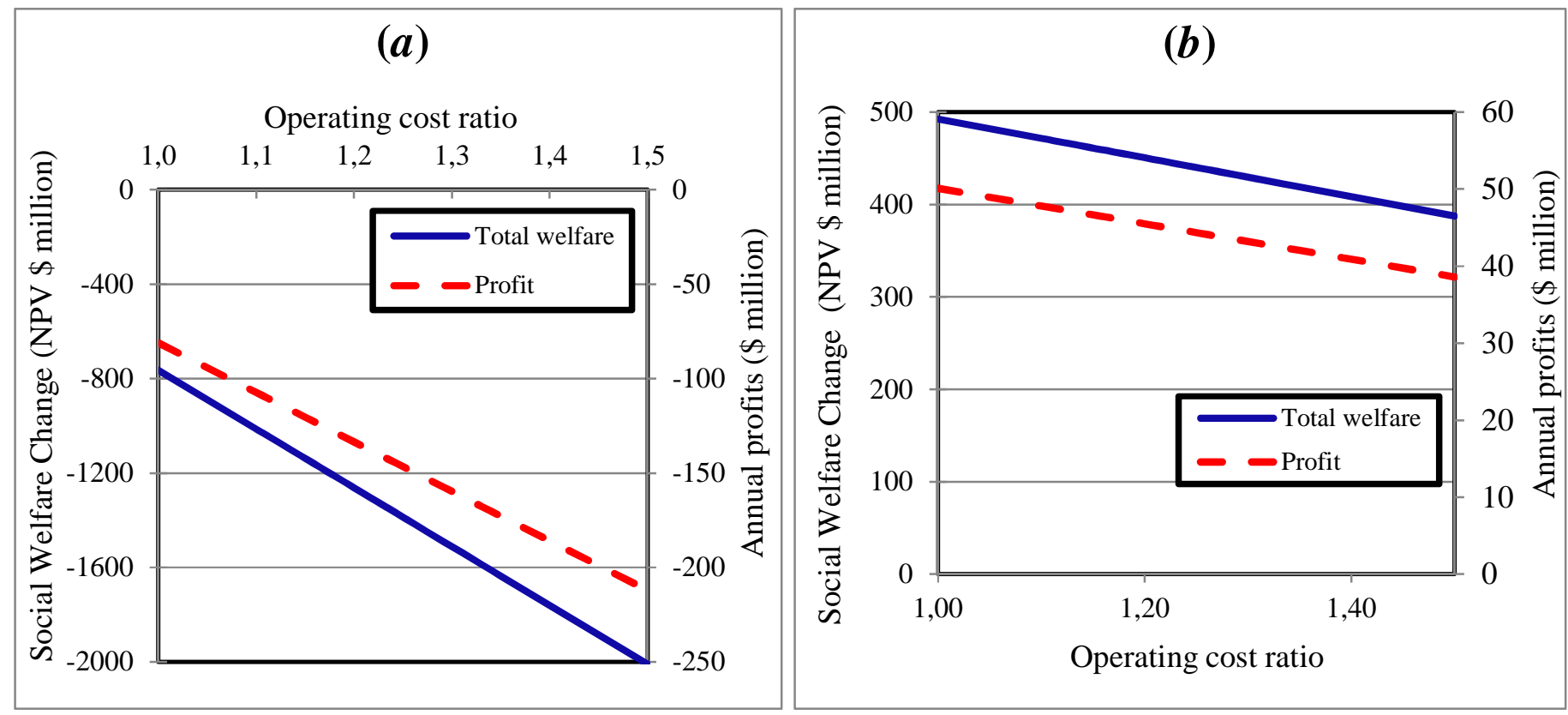

Fig.7. Sensitivity of total social welfare change to public-private operating cost ratios for Case $5(a)$, and Case 7 (b). 
Table 1.

Major features of alternative IP3 schemes

\begin{tabular}{ccccc}
\hline & Concession roads & Objective Function & Operator & Toll cap \\
\hline Case 1 & HW1 & Profit maximization & Private & No limit \\
Case 2 & Individual roads & Profit maximization & Private & No limit \\
Case 3 & Monopoly (all) & Profit maximization & Private & No limit \\
Case 4 & Oligopoly (all) & Profit maximization & Private & No limit \\
Case 5 & System optimal pricing & System cost minimization & Public & Limited \\
Case 6 & Two private HWs & Profit maximization & Private & Limited \\
Case 7 & $\begin{array}{c}\text { Two private HWs \& one } \\
\text { public HW }\end{array}$ & Combination & Private \& Public & Limited \\
\hline
\end{tabular}


Table 2.

The overall outcomes of alternative schemes

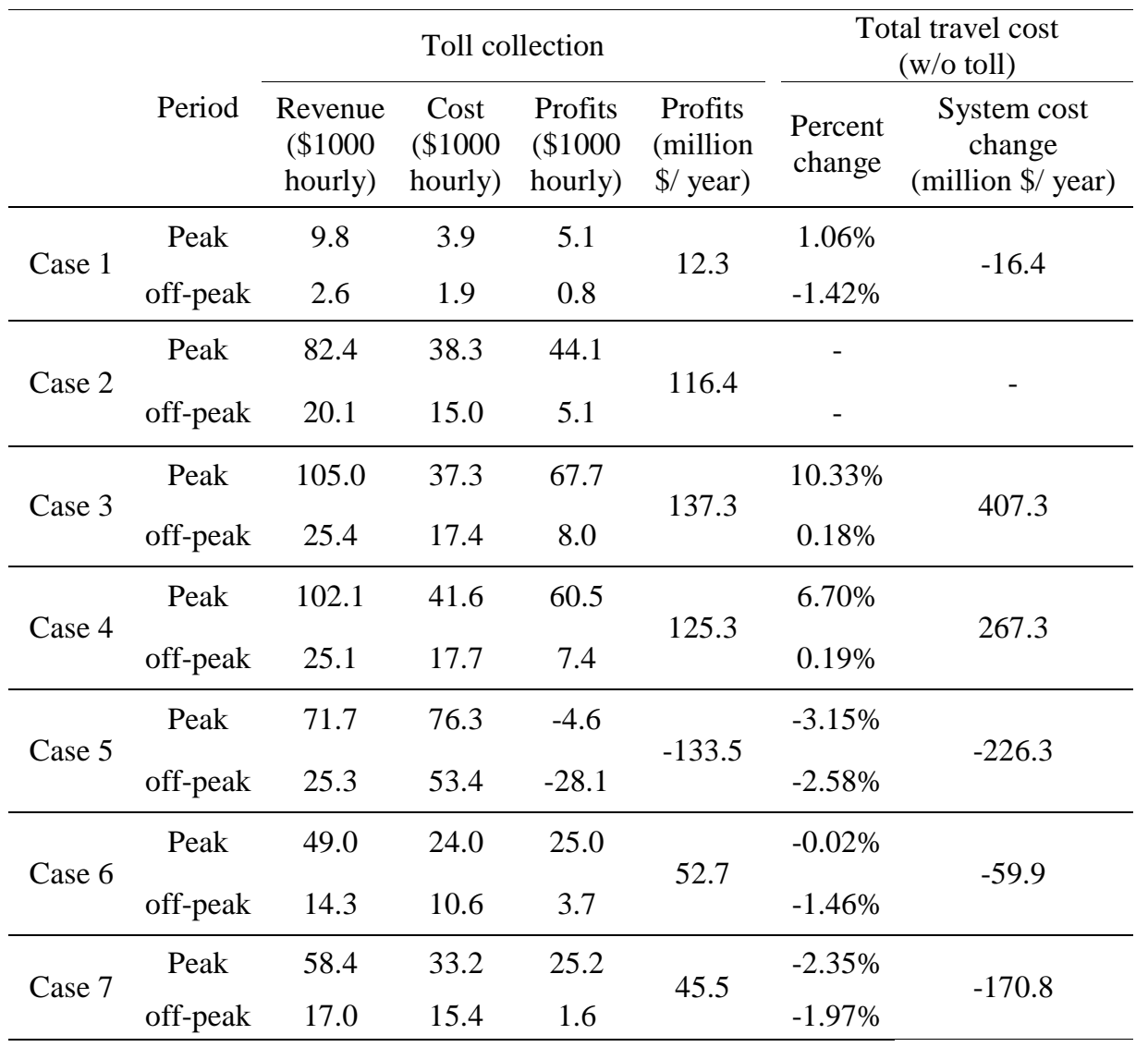


Table 3.

The government and private sector gains and losses under different scenario cases

\begin{tabular}{|c|c|c|c|c|c|c|c|}
\hline & \multicolumn{3}{|c|}{ Toll Collection system } & \multicolumn{3}{|c|}{ Government } & \multirow{2}{*}{$\begin{array}{c}\begin{array}{c}\text { Private } \\
\text { sector }\end{array} \\
\begin{array}{c}\text { Profits } \\
\text { (million \$) }\end{array}\end{array}$} \\
\hline & $\begin{array}{c}\text { Revenue } \\
(\text { million \$) }\end{array}$ & $\begin{array}{c}\text { Cost } \\
(\text { million } \$)\end{array}$ & $\begin{array}{c}\text { Profit } \\
\text { (million \$) }\end{array}$ & $\begin{array}{c}\text { 1-Profits } \\
\text { from IP3 } \\
\text { (million \$) }\end{array}$ & $\begin{array}{l}\text { 2-Profits } \\
\text { from } \\
\text { public tolls } \\
\text { (million \$) }\end{array}$ & $\begin{array}{c}\text { Profits } \\
1+2 \\
\text { (million \$) }\end{array}$ & \\
\hline Case 1 & 26.1 & 14.1 & 12.0 & 1.2 & - & 1.2 & 3.6 \\
\hline Case 2 & 203.5 & 87.1 & 116.4 & 11.6 & - & 11.6 & 34.9 \\
\hline Case 3 & 271.5 & 134.2 & 137.3 & 13.7 & - & 13.7 & 41.2 \\
\hline Case 4 & 267.0 & 141.7 & 125.3 & 12.5 & - & 12.5 & 37.6 \\
\hline Case 5 & 221.2 & 354.7 & -133.5 & - & -133.5 & -133.5 & - \\
\hline Case 6 & 138.0 & 83.5 & 54.6 & 5.5 & - & 5.5 & 16.4 \\
\hline Case 7 & 164.3 & 118.8 & 45.5 & 4.8 & -2.9 & 1.7 & 14.5 \\
\hline
\end{tabular}


Table 4.

Residents' and users' gains and losses under different scenario cases

\begin{tabular}{|c|c|c|c|c|c|c|c|}
\hline & \multicolumn{4}{|c|}{ Average users } & \multicolumn{3}{|c|}{ Residents } \\
\hline & $\begin{array}{l}\text { (1) Paid tolls } \\
\text { (\$ per user) }\end{array}$ & $\begin{array}{l}\text { (2) Change } \\
\text { in other } \\
\text { travel costs } \\
\text { (\$ per user) }\end{array}$ & $\begin{array}{l}\text { (3) Social } \\
\text { cost- demand } \\
\text { decrease } \\
\text { (\$ per user) }\end{array}$ & $\begin{array}{c}\text { Total } \\
\text { change } \\
1+2+3(\$ \\
\text { per user })\end{array}$ & $\begin{array}{l}\text { (1) Benefits of } \\
\text { fewer } \\
\text { emissions }(\$ \\
\text { per person) }\end{array}$ & $\begin{array}{c}\text { (2-a) dividends } \\
\text { of } 20 \text { year conc. } \\
\text { (\$ per person) }\end{array}$ & $\begin{array}{l}\text { (2-b) dividends } \\
\text { of } 50 \text { year conc } \\
\text { (\$ per person) }\end{array}$ \\
\hline Case 1 & 57.4 & -21.9 & 0.1 & 35.6 & 0.8 & 21.9 & 19.1 \\
\hline Case 2 & - & - & - & - & - & 212.1 & 181.1 \\
\hline Case 3 & 593.6 & 900.1 & 8.3 & 1502.0 & -14.7 & 250.2 & 214.0 \\
\hline Case 4 & 580.6 & 589.7 & 7.1 & 1177.5 & -9.6 & 228.3 & 194.5 \\
\hline Case 5 & 478.9 & -482.8 & 2.3 & -1.7 & 8.4 & - & - \\
\hline Case 6 & 297.6 & -127.7 & 1.5 & 171.4 & 2.3 & 96 & 82.1 \\
\hline Case 7 & 356.2 & -364.5 & 1.8 & -6.6 & 6.5 & 82.9 & 70.7 \\
\hline
\end{tabular}


Table 5.

Total welfare over a 20 -year concession period

\begin{tabular}{cccccc}
\hline & $\begin{array}{c}\text { Residents } \\
(\text { million \$) }\end{array}$ & $\begin{array}{c}\text { Government } \\
(\text { million \$) }\end{array}$ & $\begin{array}{c}\text { Private sector } \\
(\text { million \$) }\end{array}$ & $\begin{array}{c}\text { Users } \\
\text { (million \$) }\end{array}$ & $\begin{array}{c}\text { Total welfare } \\
\text { (million \$) }\end{array}$ \\
\hline Case 1 & 69 & 11 & 34 & -185 & -71 \\
Case 3 & 784 & 131 & 392 & -7780 & -6474 \\
Case 4 & 716 & 119 & 358 & -6104 & -4911 \\
Case 5 & 0 & -1271 & 0 & 9 & -1262 \\
Case 6 & 312 & 52 & 156 & -891 & -371 \\
Case 7 & 260 & 18 & 138 & 34 & 451 \\
\hline
\end{tabular}


Table 6.

Dividends under different demand risk rates

\begin{tabular}{|c|c|c|c|c|c|}
\hline & \multirow{2}{*}{ Concession roads } & \multicolumn{2}{|c|}{$\begin{array}{l}\text { (2-a) dividends of } 20 \text { year } \\
\text { conc. ( } \$ \text { per person) }\end{array}$} & \multicolumn{2}{|c|}{$\begin{array}{l}\text { (2-b) dividends of } 50 \text { year } \\
\text { conc. (\$ per person) }\end{array}$} \\
\hline & & $\begin{array}{l}\text { Demand risk } \\
4 \%\end{array}$ & $\begin{array}{c}\text { Demand risk } \\
10 \%\end{array}$ & $\begin{array}{c}\text { Demand risk } \\
4 \%\end{array}$ & $\begin{array}{c}\text { Demand risk } \\
10 \%\end{array}$ \\
\hline Case 1 & HW1 & 21.9 & 19.9 & 19.1 & 15.5 \\
\hline Case 2 & Individual roads & 212.1 & 188.1 & 181.1 & 146.7 \\
\hline Case 3 & Monopoly (all) & 250.2 & 222.0 & 214.0 & 173.2 \\
\hline Case 4 & Oligopoly (all) & 228.3 & 202.1 & 194.5 & 157.6 \\
\hline Case 5 & $\begin{array}{l}\text { System optimal } \\
\text { pricing* }\end{array}$ & - & - & - & - \\
\hline Case 6 & Two private HWs & 99.5 & 85.2 & 82.1 & 66.4 \\
\hline Case 7 & $\begin{array}{c}\text { Two private HW \& } \\
\text { one public HW }\end{array}$ & 82.9 & 73.6 & 70.7 & 57.3 \\
\hline
\end{tabular}

* For this case the public sector cannot pay dividend to residents. However, the corresponding dividends that residents should pay are: $243.3,216,207.7$, and 168.2 , respectively. 